\title{
Large Extracellular Vesicles: Have We Found the Holy Grail of Inflammation?
}

\author{
Artur Słomka ${ }^{1}$, Sabine Katharina Urban ${ }^{2}$, Veronika Lukacs-Kornek ${ }^{3}$, Ewa Żekanowska ${ }^{1}$ \\ and Miroslaw Kornek ${ }^{4 *}$
}

${ }^{1}$ Department of Pathophysiology, Nicolaus Copernicus University in Toruń, Ludwik Rydygier Collegium Medicum, Bydgoszcz, Poland, ${ }^{2}$ Department of Medicine II, Saarland University Medical Center, Saarland University, Homburg, Germany, ${ }^{3}$ Institute of Experimental Immunology, University Hospital of the Rheinische Friedrich-Wilhelms-University, Bonn, Germany,

${ }^{4}$ Department of Oncology, Hematology and Rheumatology, University Hospital Bonn, Bonn, Germany

The terms microparticles (MPs) and microvesicles (MVs) refer to large extracellular vesicles (EVs) generated from a broad spectrum of cells upon its activation or death by apoptosis. The unique surface antigens of MPs/MVs allow for the identification of their cellular origin as well as its functional characterization. Two basic aspects of MP/MV functions in physiology and pathological conditions are widely considered. Firstly, it has become evident that large EVs have strong procoagulant properties. Secondly, experimental and clinical studies have shown that MPs/MVs play a crucial role in the pathophysiology of inflammation-associated disorders. A cardinal feature of these disorders is an enhanced generation of platelets-, endothelial-, and leukocyte-derived EVs. Nevertheless, anti-inflammatory effects of miscellaneous EV types have also been described, which provided important new insights into the large EV-inflammation axis. Advances in understanding the biology of MPs/MVs have led to the preparation of this review article aimed at discussing the association between large EVs and inflammation, depending on their cellular origin.

Keywords: microvesicles and exosomes, inflammation, platelet-derived microvesicles, leukocyte-derived microvesicles, endothelial-derived microvesicles

\section{EXTRACELLULAR VESICLES AT A GLANCE}

The story of EVs started in 1946, when Chargaff and West (1) reported that prolonged centrifugation of human plasma $(31,000 \times \mathrm{g}$ per $150 \mathrm{~min})$ resulted in extending the coagulation time due to loss of the "clotting factor." In 1967, Wolf (2) identified platelet-derived vesicles, which were named "platelet dust" - his paper is considered a milestone in EV research by many authors. Fourteen years later, Trams and colleagues (3) for the first time used the term "exosomes" to describe vesicles released from normal and neoplastic cell cultures. A series of studies by Johnstone et al. focusing on the role of exosomes during blood reticulocyte maturation (4-6) also need to be mentioned, in which the authors concluded that exosome shedding leads to loss of some plasma membrane functions (4) due to the elimination of redundant membrane proteins (6). Undoubtedly, the findings of these studies helped to understand that exosomes may perform crucial roles in cellular functioning and that they are not just cellular remainder.

In recent years, there have been major advances in the understanding of the biology of EVs. However, the accurate definition of EVs is still a matter of debate. There are many reasons why it is still difficult to establish a clear, meticulous definition of EVs, for example the fact 
that they are released from many cell types which results in their varied compositions and functions. Moreover, they are released via multiple mechanisms. Also, EVs exhibit various sizes (30-2,000 $\mathrm{nm}$ in diameter), therefore many different analytical methods are used for their isolation and identification from the extracellular milieu (7).

In late 2014, the International Society for Extracellular Vesicles (ISEV) published a statement paper on minimal experimental requirements for the definition of EVs and their functions (8). The authors present basic steps of the research that are required for obtaining accurate results on EVs, including separation, characterization and functional studies (8). However, these recommendations should be continually reviewed (9).

Another aspect that needs to be emphasized is that, starting from 2004, the most common term for EVs used in literature is the "exosome" (or "exosomes") (8), however many other terms are also applied to describe EV subtypes; the terminology is constantly evolving. Currently, in order to systematize the knowledge on EVs, three main EV types are recognized: exosomes, microvesicles (MVs; microparticles, MPs; ectosomes), and apoptotic bodies (apoptotic vesicles) (10). All of these EV subtypes have common denominators, for example: they are nano-sized vesicles composed of phospholipid bilayers with a spheroidal shape and contain membrane and cytosolic proteins, receptors, and nucleic acids originating from their cell of origin (11). Notwithstanding, the diversity of EV antigens can also be considered a feature that differentiates EVs in terms of cellular origin and functions. Indeed, an Internet compendium of exosomal cargo, ExoCarta, (http://www.exocarta.org) contains data on 41,860 proteins, over 7,540 RNAs and 1,116 lipids identified in exosomes in multiple organisms (12). Two other online databases, EVpedia (http://www.evpedia.info) (13) and Vesiclepedia (14) (http://www.microvesicles.org) present information on all EV types including, but not limited to, exosomes.

Recently, ISEV proposed to classify EVs on the basis of centrifugation conditions into: EVs sedimenting at 100,000 $\times \mathrm{g}$ into small EVs (sEVs) rather than exosomes; EVs sedimenting at speeds lower than $20,000 \times \mathrm{g}$ into medium EVs (mEVs, microvesicles, ectosomes), and EVs sedimenting at 2,000 $\times$ g into large EVs (lEVs, large fragments of cells, large apoptotic bodies) (15). Since these recommendations are relatively new (dated March 2017), most authors still use previous, long-established terms. Numerous excellent reviews on EV biogenesis, including their formation and secretion, have already been published $(16,17)$, thus, in the current review, we provide only a brief description of the two main EV populations: small (exosomes) and medium EVs (microvesicles).

\section{EXOSOMES-A SHORT PRESENTATION}

Exosomes are the smallest among all the EV subtypes (30$150 \mathrm{~nm}$ ) and their density ranges between 1.10 and $1.19 \mathrm{~g} / \mathrm{mL}$. They are secreted by many physiological cell types (18-37) summarized in Table 1. The presence of exosomes in different biological fluids is well researched (38-52); cancer cells are also known to have the ability to release exosomes (53). Most exosomes are secreted from multivesicular bodies (MVBs) (16), also known as multivesicular elements (MVEs), late endosomes or endocytic carrier vesicles $(54,55)$. In vivo experiments elegantly demonstrated that MVBs are organelles containing intraluminal vesicles (ILVs), which release exosomes into the extracellular space upon fusion with the plasma membrane (54). In contrast, $\mathrm{T}$ cells may release exosomes directly from discrete domains of the plasma membrane (56). Two sophisticated mechanisms are engaged in exosome generation. One of them depends on the ESCRT (endosomal sorting complex required for transport) machinery (57), while the other one is ESCRTindependent (58). Naturally, not all ILVs become exosomes, since part of MVBs fuse with lysosomes and undergo destruction (Figure 1) (58). Tetraspanins (CD9, CD63, CD37, CD81, CD82), heat shock proteins (HSPs), tumor susceptibility gene 101 protein (Tsg101), and ALG-2-interacting protein X (Alix) are all antigens commonly expressed on the exosomes surface $(11,59)$. With reference to ExoCarta (12), CD9 is the major exosomal antigen identified in 98 different studies. Importantly, basic studies conducted in the past several years have confirmed that exosomes are predominantly involved in cell-to-cell interactions (60-62).

\section{MICROVESICLES (MICROPARTICLES) -A SHORT PRESENTATION}

Each EV type is unique with regard to size and biogenesis. Analysis of MVs from human cells and cell cultures reveal that they are plasma membrane vesicles with diameters ranging from 100 to $1,000 \mathrm{~nm}(1 \mu \mathrm{m})(17)$. Nevertheless, similarly to exosomes, a uniformly accepted definition of MVs is not available. One noteworthy description was proposed by Shet et al. (63), who characterized MVs as vesicles: obtained via ultracentrifugation, with a size of $\leq 1000 \mathrm{~nm}$ and expressing phosphatidylserine (PS) verified by annexin $\mathrm{V}$-positive staining. In contrast, the group of Connor et al. (64) described the existence of annexin Vnegative MVs. Of note, some authors studying MVs define them as exosomes or use these two concepts as synonyms, which is incorrect. Under both physiological and pathological conditions, MVs are released from cytoplasmic membrane, and engrossingly, the same cells may produce exosomes and MVs concurrently $(18,21)$. MVs may be released from multiple cell types, including platelets (18), erythrocytes (65), leukocytes [neutrophils (21, 66), monocytes (67), T, and B lymphocytes (67)], brain cells $(68,69)$, dendritic cells (70), adipocytes (71), endothelial cells (72, 73), endothelial progenitor cells (74), hepatocytes (75), and by hardly ever researched photoreceptors (76) as well as by tumor cells $(16,17)$. Subsequently, numerous reports describe the occurrence of MVs in biological fluids. Typically, peripheral blood (67) is a standard material for MV isolation and characterization. Other MV-containing fluids are cord blood (77), urine (78), cerebrospinal fluid (79), saliva (80), amniotic fluid (81), synovial fluid (82), and vitreous fluid (76). Despite the naturally occurring biological fluids, evidence suggests that MVs are present in bronchoalveolar lavage fluid (BALF) (83), ascites, pleural, chyloid, and postoperative drainage fluid (84), 
TABLE 1 | Exosome characteristics according to type of parental cell.

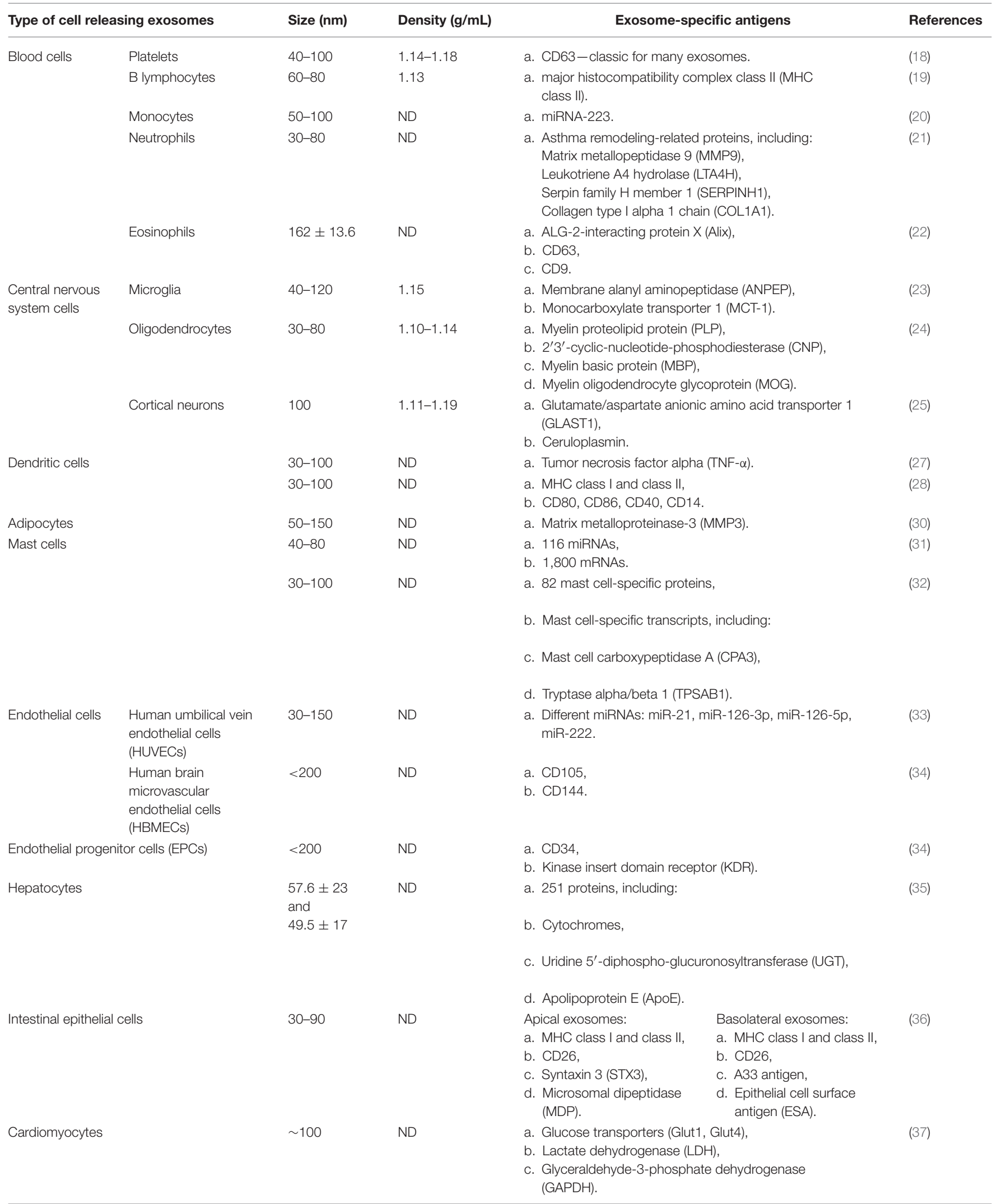

ND, not determined. 


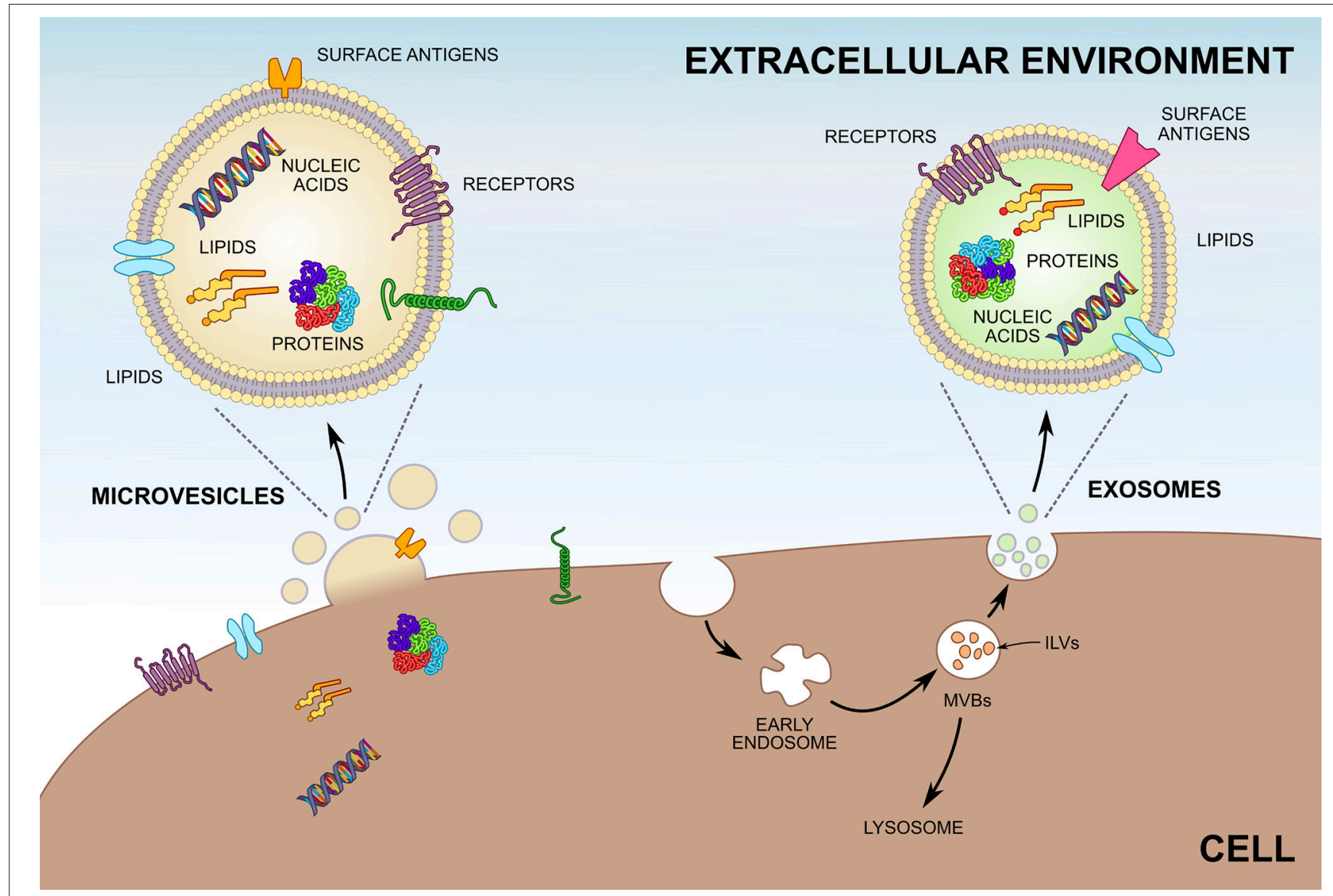

FIGURE 1 | Biogenesis of microvesicles (MVs) and exosomes. Unlike MVs, which are shedded directly from the plasma membrane, most exosomes are formed by invagination of endosomes and are stored within multivesicular bodies (MVBs) before release. Exosomes inside MVBs are also called intraluminal vesicles (ILVs). Upon fusion of MVBs with the plasma membrane exosomes are released into the extracellular environment. Both MVs and exosomes enclose greatly varying compositions of proteins, lipids, and nucleic acids and can be characterized by differing surface antigens.

and likewise can be isolated from atherosclerotic plaques (85). Data gathered from experimental and clinical investigations have implied that MVs are shedding from plasma membranes upon cell activation and apoptosis and that the antigenic expression of endothelial (86), platelet (87), and monocytic (88) MVs depends on the type of stimulus. Given that MVs are fragments of cell membranes, it might seem that their release does not require convoluted biochemical processes. In reality, they are multi-stage processes the mechanisms of which are not yet fully understood (89). As can be deducted from Table 2, antigens of parental cells can be used to identify MVs in biological fluids as well as in conditioned media from cultured tissues. Moreover, the results of in vitro and in vivo studies, although not unanimously (64), suggest that the vast majority of MVs expose PS. The review of literature also shows that many scientists largely focused their attention on another MV surface antigen, namely tissue factor (TF). Thus, TF-bearing MVs are increasingly being used to evaluate thromboembolic complications in different pathological conditions (90), including cardiovascular diseases $(91,92)$ and cancer (93). The great variety of bioactive molecules (proteins, lipids, and nucleic acids) which can be transported by MVs from cell to cell enables these nano-sized particles to perform many functions in coagulation, inflammation, cancer, and angiogenesis (94). In this paper we will review current state of knowledge on the role of MVs in inflammation and inflammatory-related disorders.

\section{PLATELET-DERIVED MICROVESICLES (PMVs) AND INFLAMMATION}

Platelets are small, anucleated cellular elements derived from megakaryocytes which play substantial role in blood coagulation (95). It is generally recognized that platelets are effectively the root cause of circulating MVs. As discussed by Kornek and Schuppan (96), platelet-derived MVs (PMVs) constitute the most commonly researched MV type. Furthermore, PMVs represent predominant fraction of MVs in circulation (97). Flow cytometry is commonly used to determine the number of PMVs in biological fluids by using monoclonal antibodies against glycoprotein IIb (CD41), glycoprotein IIIa (CD61), and P-selectin (CD62P) (98). 
This section of the article contains the summary of current state of knowledge on the role of PMVs in inflammation, although they can also be found in biological fluids of healthy organisms. In order to improve understanding of PMVs' role in physiological conditions, Berckmans et al. (97) conducted a study which showed that PMVs have anticoagulant properties thanks to protein $\mathrm{C}(\mathrm{PC})$ activation. It is also interesting that the function of megakaryocytes as the main source of PMVs in healthy subjects was confirmed in another research (99).

Two types of observations point at the significance of PMVs in inflammation. First, a number of experimental researchers reported that PMV cargo can interact with cells involved in inflammatory reactions. Second, an increase in blood PMV levels has been reported in inflammatoryassociated disorders. Essentially, the proinflammatory action of PMVs comes down to modulation of several processes, including activation of both immune cells and endothelium, intensification of leukocyte transendothelial migration (TEM) and cell to cell interaction, stimulation of chemotaxis, and reducing apoptosis of inflammatory cells. Moreover, PMVs remain a rich potential source of proinflammatory cytokines and complement components. At the beginning of the $\mathrm{MV}$ era it was comprehensively accepted that PMVs are strong proinflammatory mediators. This is partially true and also obviously incomplete since recent studies documented that PMVs serve as anti-inflammatory factors $(11,16,94,96)$. This missing aspect will be discussed in the subsequent part of this section.

One universal concept that has emerged from previous studies is that PMVs modulate the phenotype of different cells via transport of their bioactive components to target cells. The observation that PMVs can activate a great variety of cells which are engaged in both immunity and inflammation allowed major progress in the understanding of interdependence between inflammatory processes and PMVs. This mechanism was studied in detail by Barry et al. $(100,101)$ in the late 90 s. In the initial report, they proved that PMVs induce expression of cyclooxygenase-2 (COX-2) and prostacyclin $\left(\mathrm{PGI}_{2}\right)$ production in endothelial cells (100) throughout arachidonic acid (AA). This observation initiated a series of studies on the possibility of shifting endothelial properties into a proinflammatory state with PMV participation. The authors further noted that interaction between monocytes and endothelial cells is modulated by PMVs (101). This data clearly indicates that PMVs have the ability to activate intracellular cell adhesion molecule-1 (ICAM1, CD54) on endothelial cells and integrin subunit alpha L (CD11a), integrin subunit alpha M (CD11b), and CD14 on blood monocytes as well as on the U-937 macrophage cell line (101). All of these surface antigens are crucial in inflammation. ICAM-1 interacts with two types of leukocyte receptors: lymphocyte function-associated antigen 1 (LFA-1, CD11a-CD18) and macrophage-1 antigen (Mac-1, CD11bCD18), which is the key step leading to TEM (102). This complex process, so called diapedesis, recruits leukocytes to the site of inflammation (103). Interestingly, the chemotaxis of U-937 cells also seems to be induced by PMVs (101). When examining the mechanism of monocyte recruitment to endothelium, Mause et a1. (104) reported that this process depends on chemokine (C-C motif) ligand 5 [CCL5, also known as regulated on activation, normal $\mathrm{T}$ cell expressed and secreted (RANTES)], transferred into endothelial cells by PMVs. Accordingly, an early study was conducted in order to understand the relationship between PMVs and leukocyteleukocyte interactions (105). Forlow et al. (105) demonstrated that P-selectin, which is a protein localized in the membranes of PMVs, constitutes a critical component in neutrophil aggregation and accumulation. After creating a specific bond with its primary ligand, P-selectin glycoprotein ligand-1 (PSGL1, CD162) it serves as "bridge" between circulating or adherent neutrophils (105). Other researchers proved that PMVs inhibit the apoptosis of polymorphonuclear leukocytes (PMNs) (106). Indeed, stimulation of platelets with thrombin leads to the release of PMVs, which through transforming growth factor beta 1 (TGF- $\beta 1$ ) suppress PMNs apoptosis (106). On the other hand, PMVs promote apoptosis in macrophages, probably because of the transfer of active caspase 3 (107).

The PMVs' ability to induce the adhesion of PMNs to endothelium spurred considerable interest, mostly because this process is involved in inflammatory reactions (as mentioned earlier). A study conducted by Lindemann et al. (108) concluded that interleukin (IL)-1 $\beta$ is carried by PMVs and induces human endothelial cell adhesiveness for neutrophils. Recently, Xie et al. (109) attempted to characterize the role of PMVs in endothelial cell damage. Data published by them have shown that PMVs can synergize with PMNs and together are responsible for the destruction of microvascular endothelium (109). Most notably, this reaction is dynamically modulated by the interaction of soluble CD40 ligand (sCD40L) from PMVs with CD40, a receptor found on granulocytes (109). Recognition of PMVs as a source of sCD40L is extraordinarily important for considering their role in inflammation. Despite the findings of Xie et al. (109), sCD40L is a strong proinflammatory molecule, which binds to CD40 in cells of the immune system, such as monocytes/macrophages, as well as in endothelial cells, and initiates a series of biochemical and molecular reactions, including: monocyte extravasation, cytokine synthesis [monocyte chemoattractant protein-1 (MCP-1), IL-1, IL-6, IL-8, matrix metalloproteinases (MMPs)], and reactive oxygen species (ROS) generation (110). Furthermore, proteomic analysis of PMVs revealed that they constitute a source of many proinflammatory compounds (111). While literally hundreds of proteins were detected (111), those engaged in inflammatory response belonged to the C-X-C motif chemokine family (CXCL4, CXCL7) and the C-C motif chemokine family (CCL5, CCL23). Furthermore, PMVs were shown to create macromolecular structures with immune complexes (112). Meticulous analysis proved that these structures, via presentation of autoantigens and stimulation of leukotriene production by neutrophils, bolster inflammation (112). It is noteworthy that works of other research groups confirmed that PMVs are a source of IL-1, IL-6 and tumor necrosis factor- $\alpha$ (TNF- $\alpha)(113,114)$. Without a doubt, the above-described properties of PMVs confirm their active participation in the pathogenesis of atherosclerosis and its complications. Although the formation of atherosclerotic plaques 
is a complex mechanism, leukocytes activation, adhesion, and migration as well as endothelial dysfunctions are also significant, and now it is clear that all these processes are moderated by PMVs. Accordingly, as might be expected, elevated plasma levels of PMVs were described in atherosclerosis and associated cardiovascular disease $(115,116)$.

As shown above, much effort has been made to describe the leukocyte-PMV-endothelial axis. Naturally, immunological response is not just a single-step process, but it involves an adaptive immune compartment. Indeed, this question in the context of lymphocyte relationship with PMVs remains substantially underresearched. Notwithstanding, an introductory study demonstrated that PMVs transfer CD40L (CD154) to B cells. CD40L-bearing PMVs induce IgG production, germinal center formation as well as B cell proliferation. Using an immortalized pancreatic endothelial cell line (MS-1), the authors additionally proved that PMVs are actively involved in the regulation of MCP-1 expression (117). More recently, the immunostimulatory effect of PMVs on the acquired immune system was quantified in Daudi B cell line (118). This small study illustrated that PMVs strongly induce the expression of CD86 and CD27 with simultaneous decrease of IgD expression in Daudi cells (118). The synthesis of IgG was increased when Daudi cells were co-cultured with PMVs (118). Although this data is fragmented and remains to be further investigated, the activation of the adaptive immune system is almost certainly related to the cooperation with PMVs.

In recent experiments different agonists, such as thrombin, collagen, and calcium ionophore A23187 (calcimycin) (100, 105), were used to activate platelets and MV release. Notwithstanding, it is well known that platelets may be activated during infection by contact with bacterial proteins. For example, direct evidence implicates that staphylococcal superantigenlike protein 5 (SSL5) is a powerful modulator of PMV generation (119). Major SSL5-induced PMV effects observed were linked with monocytes and provoking them to synthesize proinflammatory cytokines, including IL- $1 \beta$, TNF- $\alpha$, MCP- 1 , and MMP-9 (119). This experiment also showed that PMVs enhance the chemotaxis of monocytes (119). Moreover, PMVs contribute to the development of inflammation during enterohemorrhagic Escherichia coli-associated hemolytic uremic syndrome (EHECHUS) (120). In the acute phase of the disease patients exhibited increased levels of PMV-expressed complement component 3 (C3) and C9 (120). Release of PMVs rich in complement components and complement control proteins were stimulated by Shiga toxin and lipopolysaccharide (LPS) (120). There is also evidence that PMVs may play a role in viral infections. A study carried out at the University of Louisville provided clear evidence of transferring $\mathrm{C}-\mathrm{X}-\mathrm{C}$ chemokine receptor type 4 (CXCR4) by PMVs to $\mathrm{CD} 4^{+} / \mathrm{CXCR} 4^{-}$null cells and, in consequence, making them susceptible to infection by human immunodeficiency virus (X4-HIV) (121). It does not come as surprise that CorralesMedina et al. (122) reported increased levels of PMVs in blood of HIV-infected patients. Furthermore, increased activity of PMVs during HIV infection has been described (123). However, the intensification of PMV generation is not characteristic for all viral infections. For example, patients with dengue virus (DENV) infection exhibit reduced shedding of PMVs (124). The role of PMVs in parasitosis is poorly characterized because researches are mainly limited to malaria infection. The direct engagement of PMVs in Plasmodium falciparum infestation was documented by Faille et al. (125). Intriguingly, they have shown that PMVs preferentially bind with $P$. falciparum-parasitized red blood cells (PRBCs) (125). Despite the fact that PMVs can directly bind to human brain endothelial cells (HBECs), PRBCs adherence to HBECs is dramatically increased by PMVs, which links PMVs to cerebral malaria (125). Few clinical studies confirmed this in vitro report on the relationship between malaria, its complications and PMVs $(126,127)$. In particular, high plasma PMV levels were associated with coma depth and thrombocytopenia in patients with $P$. falciparum cerebral malaria (126). Similarly, researchers reported the existence of links between increased levels of plasma PMVs, fever and days with acute illness in P. vivax malaria (127). Collectively, these studies consistently demonstrated that acute phase response during infections may be additionally modulated by PMVs.

Traditionally, when thinking about the assessment of inflammation in everyday medical practice, each clinician pays particular attention to C-reactive protein (CRP). CRP is an acute phase reactant with two conformationally different forms: pentameric CRP (pCRP) and monomeric CRP ( $\mathrm{mCRP})$, which is the product of pCRP dissociation (128). Even though mCRP is characterized by a stronger proinflammatory potential compared to pCRP (129), previous report demonstrated that out of all the MV types PMVs are the ones to bind pCRP (130). The properties of PMVs escalate localized inflammation through the classical complement pathway activation and leukocyte recruitment into tissues (130).

The mechanism of PMVs role in inflammation is not as simple as it initially appears. Therefore, further insights into the role of PMVs in inflammation originated from previous studies showing their anti-inflammatory attributes (131-135). Unlike well-established proinflammatory effects, the mechanisms of inflammation suppression are poorly understood and, as far as we know, a limited number of papers address this issue. It should also be emphasized that anti-inflammatory properties of PMVs are primarily due to the inhibition of cytokine release. First, PMV cargo serves as signaling molecules to inhibit inflammatory reaction. By way of illustration, lipoxygenase 12 (12-LO) positive PMVs are thought to be involved as mediators in the synthesis of lipoxin A4 (LXA4) by mast cells, which leads to the inhibition of inflammation (131). Second, further insights into the role of PMVs in inflammatory response regulation were gained by demonstration that PMVs reduce the release of the proinflammatory proteins TNF- $\alpha$ and IL-10 by macrophages (132). Simultaneously, the release of TGF- $\beta$ was induced by PMVs (132). Accordingly, it was speculated that differentiation between monocytes and immature dendritic cells (DCs) is downmodulated by PMVs (132). However, these results should be approached with caution, as PMVs were isolated from stored (not fresh) platelets (132). On the other hand, the ability of PMVs to participate in reprograming macrophage function was also described by Laffont et al. (133). Release of CCL4, TNF, and colony stimulating factor 1 (CSF1) was 
found to decrease in macrophages co-incubated with PMVs (133). Another investigation confirmed that PMVs reduce TNF- $\alpha$ and IL-8 secretion from plasmacytoid dendritic cells (pDCs) (134). Finally, Dinkla et al. described the inhibitory effect of PMVs on adaptive immune system (135). This study constitutes compelling evidence that regulatory $\mathrm{T}$ cells (Tregs) are suppressed to release IL-17 and interferon gamma (IFN$\gamma)$ by PMVs in a P-selectin-dependent manner (135). As can be concluded from the analysis of available literature, proinflammatory properties of PMVs constitute the greater part of the paper, whereas anti-inflammatory properties are only analyzed in a scarce number of experimental studies. Nevertheless, PMVs can combine their proinflammatory action with the ability to reduce inflammation.

\section{ENDOTHELIAL-DERIVED MICROVESICLES (EMVs) AND INFLAMMATION}

It is widely acknowledged that endothelium is a single large organ with weight of around $720 \mathrm{~g}$ and surface of $6,000 \mathrm{~m}^{2}$ (136). Endothelial cells are an important source of MVs. Altered vascular homeostasis, that is state of activation or apoptosis, is associated with the release of MVs. They are defined based on cytometric analysis of glycoprotein expression, including Eselectin (CD62E), endoglin (CD105), platelet endothelial cell adhesion molecule 1 (PECAM-1, CD31), vascular cell adhesion molecule 1 (VCAM-1, CD106), vascular endothelial cadherin (VE-cadherin, CD144), and melanoma cell adhesion molecule (MCAM, CD146) (137). Some of these surface markers are also characteristic for other MV types (137), therefore their combinations are frequently used in EMV studies, for example

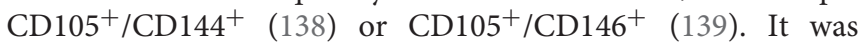
Combes et al. who for the first time provided direct evidence demonstrating the presence of EMVs in circulation (72). Since then many studies were devoted to understanding the role of EMVs in various pathological processes. Considering the origin of EMVs, literature strongly emphasizes their proatherogenic and prothrombotic action; meanwhile, the following section of this review describes the involvement of EMVs in inflammation.

Attention should be drawn to the existence of a disproportion between the number of studies on the role of EMVs in inflammation and the number of reports on PMVs. However, a growing body of evidence indicates that EMVs are also important mediators of inflammatory reactions. Discussing this issue should be initiated by the presentation of in vitro results showing that human endothelial cells release MVs after stimulation or injury with various proinflammatory cytokines. An early research conducted by a group of French scientists reported that TNF promotes EMV release by human umbilical vein endothelial cells (HUVECs) (72). Other experiments demonstrated that EMV production is increased in the presence of IL-1 $\alpha$ (140), IL-1 $\beta$ (141), IFN- $\gamma$ (141), complement proteins C5b-9 (142), CRP (143), and LPS (141). The fact that TNF strongly stimulates the release of EMVs is often used in in vitro studies (72, 86, 144-147).

The second important remark is that specific set of EMV surface proteins may modulate local and generalized inflammation. It also seems that the expression of these antigens depends on endothelial cell stimulation through inflammatory agents, first and foremost by TNF. Experimental data signify that the TNF-EMV axis is a perfect example of the inflammation cycle: TNF promotes EMV generation, which in turn increases the expression of adhesion molecules on subsequent endothelial cells. In a previously mentioned experiment designed to answer questions about the role of inflammatory stimuli on EMV generation, Combes et al. (72) found that adhesion molecule (E-selectin, ICAM-1, PECAM-1, and $\alpha v \beta 3$ ) expression on EMVs is enhanced by TNF. Moreover, there are indications that TNF- $\alpha$ induction of EMVs depends on p38 mitogenactivated protein kinase (MAPK) (145). Released EMVs act on subsequent endothelial cells, increasing the secretion of soluble ICAM-1, which does not depend on MAPK (145). It should also be stressed that this study associated EMVs with IL-6, demonstrating a very strong positive correlation between these two inflammatory components (145). The findings of Lee et al. (146) confirmed that EMVs increase endothelial surface expression of ICAM-1 in a dose-dependent manner. Among several molecular mechanisms that may contribute to EMV shedding, the authors incontrovertibly proved the role of nuclear factor kappa-light-chain-enhancer of activated B cells (NF- $\kappa \mathrm{B})$ and tumor necrosis factor receptor-1 (TNFR1) (146). As for the question of inflammation, they also described that attachment of monocytes to endothelial cells is modulated by EMVs (146). Accordingly, an earlier study (147) found the ability of EMVs to bind with monocytes. Indeed, several clinical studies identified increased binding of EMVs with leukocytes in inflammatory conditions, including severe systemic inflammatory response syndrome (SIRS) (148), metabolic syndrome (149), and multiple sclerosis (150, 151). As mentioned earlier, TNF causes increased expression of adhesion molecules, predominantly ICAM-1, both on EMVs and endothelium surface, which results in an intensified interaction between leukocytes and endothelial cells. Moreover, studies show greater affinity of EMVs to monocytes than to neutrophils and lymphocytes (150). It is also clear from experimentally induced TEM that monocyte migration is enhanced when cells are conjugated with EMVs $(150,151)$. As emphasized at the beginning of this paragraph, interactions between EMVs and endothelial cells are examples of an inflammation cycle. In the same context, Liu et al. (152) have recently confirmed that the axis of TNF-endothelium-EMV-endothelium is a self-perpetuating inflammatory process. They concluded that TNF-induced EMVs stimulate endothelial cells to produce proinflammatory cytokines including interferon gamma-induced protein 10 (IP-10) (152). Interestingly, EMVs can also be generated in the process of endothelial cell stimulation by bubbles, which represents a laboratory model of decompression sickness (DCS) (153). These bubble-induced EMVs support inflammatory responses by promotion of proinflammatory cytokine release (soluble ICAM-1 and soluble VCAM-1) (153). Collectively, the studies discussed in this section lead to the conclusion that EMVs have the ability to activate both endothelium and leukocytes, which fortifies migration of leukocytes to the site of inflammation. Recently, Nakaoka et al. (154) have put forward important 
and thought-provoking observations on the proinflammatory mechanism of EMV. First, two unique microRNAs (hsamiR-145-5p and hsa-miR-320a) were encapsulated in EMVs. Second, hsa-miR-145-5p and hsa-miR-320a were transferred to monocytes and upregulated mRNAs of inflammatory cytokines (TNF- $\alpha$, IL-1 $\beta$, IL-6, IL-10, and IL-18) (154). In another study by Yamamoto et al. (141) the researchers tried to identify the effect of inflammation-induced EMVs on pericytes. These findings indicate that the release of EMVs in response to inflammatory factors is incorporated into cerebrovascular pericytes and increase vascular endothelial growth factor B (VEGF-B) mRNA and protein expression in a miRNA-dependent manner (141). Unquestionably, this aspect also links EMVs to the process of angiogenesis. On the contrary, experiments reported by Jansen et al. (155) showed that EMVs reduce ICAM-1 expression by transporting miR-222 to endothelial cells. This apparently results in a decrease of monocyte adhesion to endothelium (155). Detailed studies on the mechanisms by which microRNAs associated with EMVs modulate inflammatory reactions are in a relatively early phase of development, however it may already be speculated that the trend in proinflammatory vs. anti-inflammatory properties depends on the type of microRNA.

Only few reports are currently available on the role of EMVs in adaptive immunity modulation. It is important to remember that EMVs activate lymphocyte proinflammatory pathways through surface antigens. Notably, previous work demonstrated that EMVs induce maturation of plasmacytoid dendritic cells (pDCs) (156). PDCs produce great amounts of type I interferons (IFN$\alpha$, IFN- $\beta$, IFN- $\omega$ ), type III interferons (IFN- $\lambda 1$, IFN- $\lambda 2$, IFN$\lambda 3)$, as well as IL-6, and TNF- $\alpha(157,158)$. Thus, it has been convincingly shown that after stimulation with EMVs pDCs secrete IL-6 and IL-8. Fundamentally, this study also identified increased naive $\mathrm{CD} 4+\mathrm{T}$ cell proliferation and Th1 cytokine secretion in the presence of EMV-induced mature pDCs (156). Moreover, EMVs support proliferation of $\mathrm{CD} 4+$ and $\mathrm{CD} 8+$ $\mathrm{T}$ cells (73). The presence of molecules engaged in antigen presentation and $\mathrm{T}$ cell stimulation, including $\mathrm{CD} 40$, major histocompatibility complex (MHC) class I and class II, and inducible $\mathrm{T}$ cell costimulator ligand (ICOSL) was reported on EMV surface (73). This finding, combined with the observation that EMVs bind with CD4+ and CD8+ T cells, may provide another explanation on how EMVs modulate immune response. Other observations support the view that EMVs act as activators of $\mathrm{T}$ cells response $(159,160)$. The number of Th1 cells increased when peripheral blood mononuclear cells were co-incubated with EMVs (159). An increase in T-box transcription factor (Tbet) mRNA and protein was documented simultaneously during the same experiment (159). Thus, it may be speculated that EMVs use T-bet to promote Th1 cell differentiation and cytokine synthesis. Subsequent research demonstrated that EMVs deliver miR-155 to T cells (160). Although encapsulated miR-155 does not influence proliferation and apoptosis of $\mathrm{T}$ cells, miR-155 inhibition causes suppression of IFN- $\gamma$, IL-2, IL-9, and IL-17A release, while increasing the release of other cytokines such as IL-4, IL-6, and IL-10 (160). Clinical implication derived from the above mentioned papers $(159,160)$ is that changes in $\mathrm{T}$ cell functioning under the influence of EMVs constitute critical element of pathophysiology of some disorders such as acute coronary syndrome (ACS) (159) and acute graft-versushost disease (aGvHD) (160). Accordingly, EMVs may constitute therapeutic target for anti-inflammatory drugs.

Previous investigations contributed to better understanding of dependence between EMVs and the already mentioned wellknown acute-phase reactant, CRP. In order to investigate possible interaction between CRP and EMVs, Wang et al. (143) carried out an experiment showing that endothelial cells treated with CRP release more EMVs. This observation is concurrent with data obtained by Devaraj et al. (161). The question arouse if EMVs can carry CRP and what potential biological effect of this phenomenon would be. Experimental and clinical data support potential relationship between EMVs and CRP. Major advance in our understanding of this link came when Habersberger et al. (162) reported that EMVs are involved in the conversion of pCRP to mCRP and transport mCRP to endothelial cells causing their activation as determined by an increase in VCAM-1 surface expression. Crawford et al. (163) recently confirmed that EMVs bear strong proinflammatory mCRP which may enhance TEM of monocytes. Moreover, the number of circulating EMVs correlates with CRP levels in some pathological conditions, such as coronary heart disease (164), chronic kidney disease (165), and familial Mediterranean fever (166).

In the view of pleiotropic nature of EMVs actions, it is not surprising that several studies investigated their roles in infectiology, including bacterial sepsis, viral and malaria infections. Nevertheless, more research needs to be performed in order to gain better understanding of the role of EMVs in bacterial sepsis. Sepsis is a severe and generalized inflammatory reaction in response to infection, which in consequence may lead to increased generation of main types of MVs (167). Another factor critically important for the role of EMVs in sepsis is their relationship with septic complications, primarily with disseminated intravascular coagulopathy (DIC). In a study conducted on adult patients with septic shock due to bacterial infections, Delabranche et al. (168) reported that EMVs may constitute a biomarker for DIC. Moreover, Matsumoto et al. (169) concluded that enhanced generation of EMVs signalizes extensive endothelial injury in sepsis-induced DIC. In contrast, it has recently been shown that MVs isolated from patients with septic shock, including that of endothelial origin, exhibit vasculoprotective effects working against vascular hyporeactivity (170). This may partially explain previous observations made by the group lead by Soriano (171), which described three fundamental pathophysiologic changes associated with sepsis related to EMVs. First, the number of EMVs is increased in sepsis patients in comparison to healthy control group. Second, both EMV and EMV-monocyte conjugate levels are higher in survivors compared with non-survivors. Third, lower levels of EMVs and EMV-monocyte conjugates are associated with organ dysfunction (171). Therefore, an important conclusion of these studies $(170,171)$ is that EMVs in sepsis may perform a protective role.

Although partial progress has been made in the understanding of the role of EMVs in bacterial infections, little is known about the relationship between EMVs and viral infections. 
In short, promoting a release of EMVs may be considered common feature of viral infections. For example, elevated numbers of EMVs have been described in HIV-positive patients (172). Othman et al. evaluating the effects of adenovirus administration in mice (173), also reported its ability to generate EMVs. As for other type of human virus, parvovirus B19 (primate erythroparvovirus 1), release of apoptotic EMVs but not activated EMVs have been reported (174). Despite more studies being needed, these reports emphasize the association between endothelial dysfunction and viral infection. Whereas, it is accepted that EMV shedding is linked to bacterial and viral infestation, the mode of EMV action in malaria is not fully understood. One indication that EMVs are involved in malaria pathogenesis comes from a study on children with acute phase of cerebral malaria, showing increased number of EMVs (175). In order to identify the influence of $P$. falciparum infection on EMVs, Wassmer et al. (176) designed a study in which they compared EMV generation in cultures of endothelial cells in patients with uncomplicated and cerebral malaria. After stimulation with TNF, cells obtained from patients suffering from cerebral malaria released significantly more EMVs than cells from uncomplicated cases. Therefore, it is important to find out whether EMVs may be a novel therapeutic target in severe malaria. Studies researching EMVs in infectious diseases provide unique information concerning their role in immunity. Clinically, EMVs may be an excellent biomarker of endothelial dysfunction in various infections. From pathophysiological point of view they perform opposing functions, since they are able to support normal functions of endothelium in sepsis but they are also significant for genesis and evolution of infections complications.

\section{LEUKOCYTE-DERIVED MICROVESICLES (LMVs) AND INFLAMMATION}

Leukocytes (white blood cells, WBCs) gained a considerable interest as a subject of studies by a Nobel Prize winner, Paul Ehrlich (177). It is commonly assumed that they perform essential functions in immunological responses to infections (178). Currently, considerable effort is made to understand how leukocyte-derived microvesicles (LMVs) contribute to hemostasis, inflammation and angiogenesis (179), however this section of the review is intentionally limited to describing the role of LMVs in inflammatory processes.

There is some experimental evidence that LMVs may originate from monocytes (63), neutrophils (66), as well as B and T cells (67). Since this section deals in more detail with the analysis of how LMVs control inflammation, for the sake of convenience it is divided into three paragraphs, one per each cellular source. LMVs' levels are assessed in biological fluids by flow cytometry using specific antibodies against surface proteins (Table 2). Based on literature review, we claim that LMVs can act as either pro- or anti-inflammatory modules. While the proinflammatory effects are relatively well understood, the contrary effects are much less described.
Early investigations of possible roles of LMVs in inflammation concluded that leukocytes release MVs in response to stimulation by chemotactic peptides, N-formylmethionylleucyl-phenylalanine (fMLP), and IL-8 (180, 181). The results of these initial studies have also demonstrated the ability of LMVs to induce IL-6, MCP-1, and TF synthesis in endothelial cells $(180,181)$, whereas evidence from in vitro studies suggests that monocyte MVs may activate other cells than endothelial cells. Furthermore, the role of monocyte-derived MVs in inflammatory response was discussed by Cerri et al. (182), who found that monocyte/macrophage MVs up-regulate secretion of inflammatory mediators, including IL-8, MCP-1, and ICAM-1, by airway epithelial cells (182). Human lung epithelial cells were subsequently reported to increase synthesis of IL- 8 and MCP-1 after stimulation by monocyte/macrophage derived MVs (183). The observed effects were mediated by NF- $\kappa \mathrm{B}$ activation through a peroxisome proliferator-activated receptor gamma (PPAR- $\gamma$ ) dependent pathway (183). Moreover, study performed by Eyre et al. (184) indicates that podocyte stimulation by monocyte MVs induces production of MCP-1 and IL-6. In this context it is particularly important that MVs released by monocytes activate the production of TNF- $\alpha$ and IL- 6 by monocytes and macrophages (185), hence monocyte MVs work in an autocrine and paracrine mode, like EMVs. Also, monocyte and $\mathrm{T}$ cell MVs might be an important element in the regulation of cyclooxygenase 2 (COX-2), microsomal prostaglandin $\mathrm{E}$ synthase 1 (mPGES-1), and prostaglandin $\mathrm{E}_{2}\left(\mathrm{PGE}_{2}\right)$ production (186). In synovial fibroblasts, MVs derived from monocytes and $\mathrm{T}$ cells induce synthesis of inflammatory mediators (IL-6, IL-8, MCP-1, and-2) (187). To conclude, we can say that MCP-1 is the subject of many research projects concerning linking inflammation to monocyte MVs. Moreover, MVs originated from apoptotic monocytes induce ROS generation via p38 MAPK pathway in endothelial cells and enhance platelet adhesion to endothelium (188). However, in later observations, apoptotic monocyte MVs were shown to have no effect on oxidative stress (189). Given the cardinal role of ROS in inflammation (190), it is understandable that these relationships should be further examined in future studies. Furthermore, and probably more appealing to the physicians, an extensive series of clinical studies was conducted to evaluate the significance of monocyte MVs in pathogenesis of inflammation-associated disorders. It was confirmed that they constitute important elements in pathogenesis of acute myocardial infarction (92, 191), type 2 diabetes mellitus and its complications (192-194), rheumatoid arthritis (195), intracerebral hemorrhage (196), and lung cancer (197). Possible role of LMVs in sepsis has also been suggested by the finding that their levels were increased significantly in patients with severe infection (198). Some data additionally suggest that LPS stimulates the release of MVs from monocytic cell lines (199), which show proinflammatory properties, since mRNas of several cytokines were found to be up-regulated after LPS stimulation (199).

Neutrophil MVs are another essential constituent of inflammatory reactions. Stimulation of neutrophils results in releasing heterogenous MV populations, which contain hundreds of proteins, such as leukotriene $\mathrm{A}_{4}$ hydrolase 
( $\mathrm{LKHA}_{4}$ ), which also have proinflammatory effect (200). The authors showed that neutrophil MVs can move in response to a chemotactic gradient (200). There are several proinflammatory proteins recognized on the surface of neutrophil MV. In 2008 Pluskota et al. (201) identified Mac-1 integrin on MVs derived from stimulated neutrophils that activate platelets.

TABLE 2 | Microvesicle characteristics according to type of parental cell.

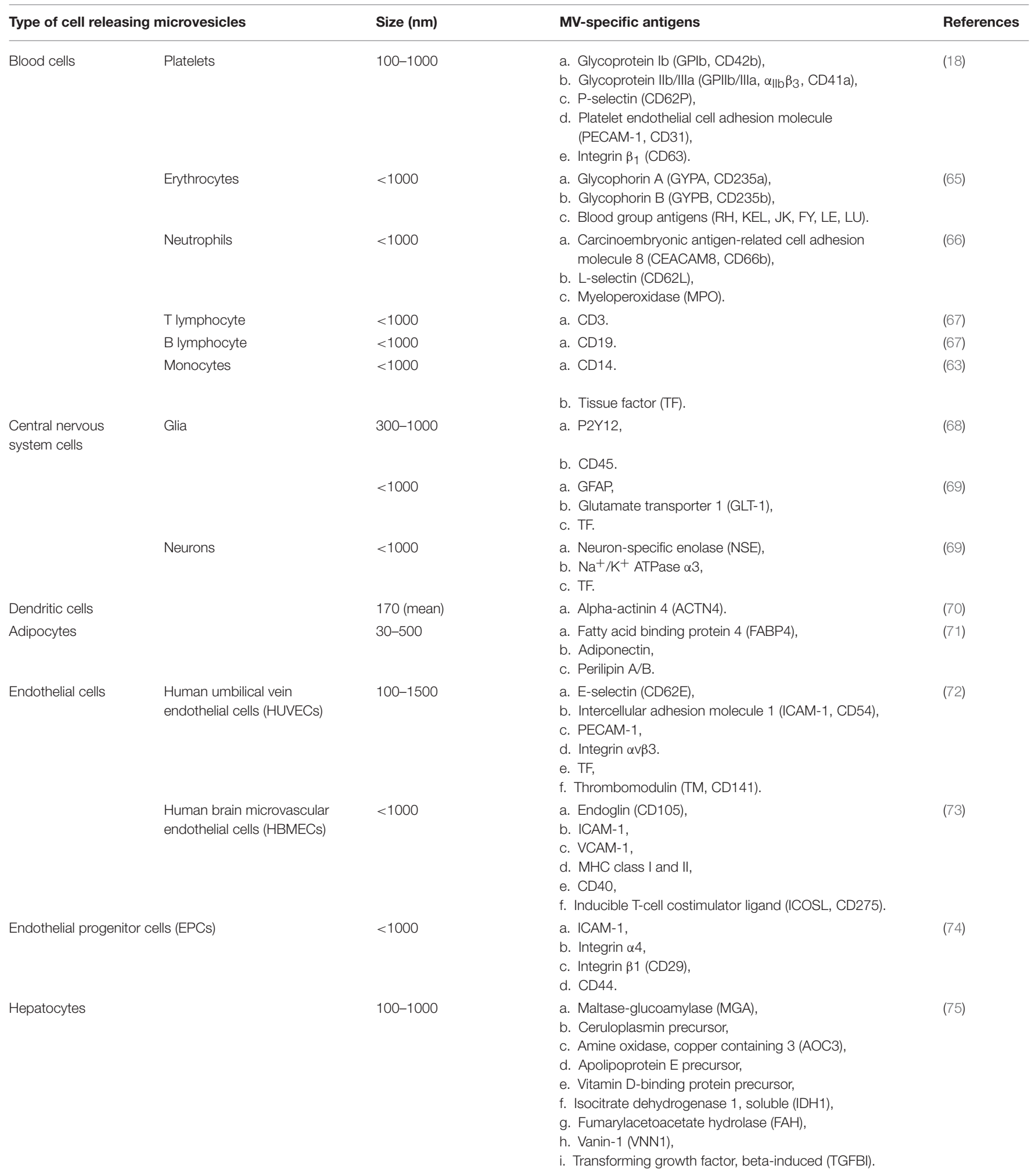


In addition to platelets, the primary effect of neutrophil MVs includes interactions with endothelial cells, which undergo a number of molecular and biochemical changes $(66,200,202,203)$. An important factor to acknowledge while considering these interactions is the observation that neutrophil MVs deliver myeloperoxidase (MPO) to endothelial cells causing their injury $(66,203)$. Furthermore, one factor that was considered to be a potential link between neutrophil MVs and inflammation is the deposition of MVs by neutrophils on intestinal epithelial cells (IECs), which promotes epithelial injury (202). The next argument in favor of the existence of link between inflammation and neutrophil MVs comes from growing clinical and experimental evidence indicating that these MVs are generated during sepsis (204-206). For example, one in vitro study showed that THP-1, a human monocytic cell line, was activated after phagocytosis of neutrophil MVs isolated from patients with sepsis (205). Accordingly, clinical observations demonstrated that patients with Staphylococcus aureus bacteremia had higher levels of neutrophil MVs in their blood than healthy controls (204). Moreover, Prakash et al. (205) found elevated levels of neutrophil MVs in abdominal fluid from patients with sepsis and peritonitis. Despite these mentioned results, the complete mechanism of neutrophil MV action in sepsis remains unknown. In fact, Timár et al. (204) extended previous observations, showing the antibacterial effects of neutrophil MVs by inhibiting bacterial growth.
The biological function of neutrophil MVs is not limited to their role as proinflammatory agents. Therefore, the antiinflammatory trend was independently confirmed in a number of studies. Experiments designed by Hyun et al. (207) and Lim et al. (208) demonstrated that neutrophil, monocytes and $\mathrm{T}$ cells deposit $\mathrm{CD}_{1}{ }^{+} \mathrm{MVs}$ at the subendothelium during extravasation, playing a protective role by preventing vascular leakage. It is important to notice that the investigation of immunosuppressive functions of neutrophil MV set the foundations for discovering that they do not induce the release of IL- 8 and TNF- $\alpha$ by macrophages (209). In the original paper describing these results, Gasser and Schifferli (209) clearly demonstrated an increased release of the anti-inflammatory mediator transforming TGF- $\beta 1$ by neutrophil MV-stimulated macrophages. Accordingly, annexin A1 (AnxA1), which is present in neutrophil MVs, induces decrease in interaction between MVs and endothelial cells (210). Lastly, neutrophil MVs are also engaged in inflammation through their involvement in cytokine production by natural killer (NK) cells (211). By measuring the levels of pro- and anti-inflammatory proteins, Pliyev et al. (211) were able to demonstrate that neutrophil MVs reduced the release of IFN $\gamma$ and TNF- $\alpha$, but enhanced the release of TGF- $\beta 1$. Altogether, this data suggests that neutrophil MVs might have different, also opposing functional roles in inflammatory response.

Three lines of direct evidence suggested that lymphocyte MVs play important role in promoting and inhibiting inflammatory

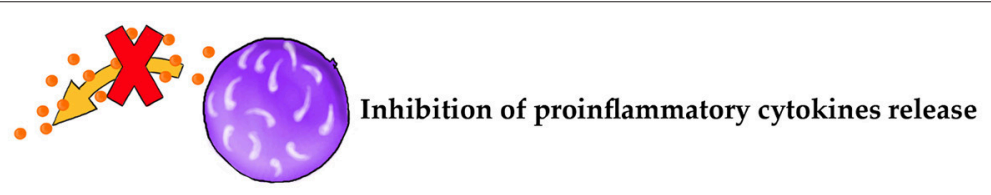

Anti-inflammatory properties

\section{Platelet, endothelial, and leukocyte microvesicles}

\section{Proinflammatory properties}
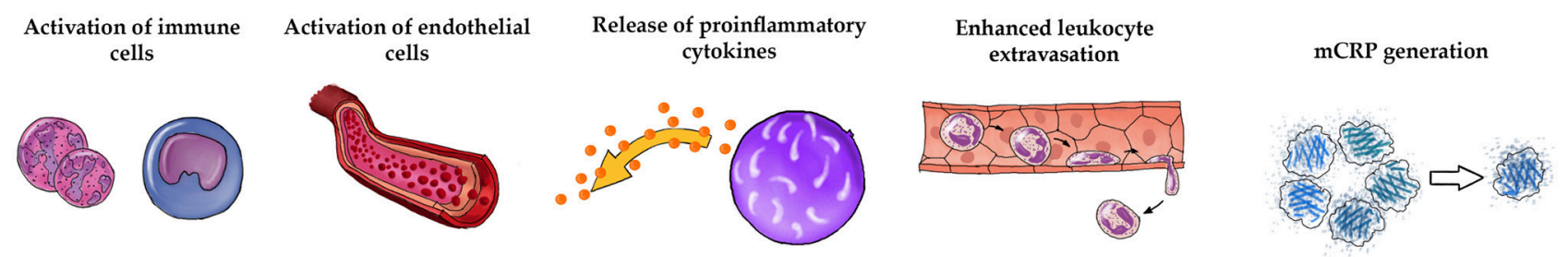

FIGURE 2 | Universal pro- and anti-inflammatory properties of MVs. The three main types of circulating MVs (PMVs, EMVs, and LMVs) exhibit common proinflammatory activities such as activation of immune cells $(73,101,105,109,117-119,147,150,154,156,159,160,185)$, activation of endothelial cells $(66,72,100,101,104,108,145,146,180,181,200,202,203)$, release of proinflammatory cytokines

(111, 113, 114, 119, 121, 152-154, 180-187, 200, 201, 212, 214), enhanced leukocyte extravasation (101, 104, 108, 130, 150, 151), and mCRP generation $(162,163)$. They also have an anti-inflammatory effect, based on the inhibition of the release of proinflammatory cytokines (132-134, 155, 209, 210). 
reaction. First, current data indicates that activated T-cells generate MVs able to collaborate with many cell types. In short, it was shown that T-cell generated MVs induce synthesis of proinflammatory (TNF, IL-1 $\beta$ ) as well as anti-inflammatory (secretory interleukin-1 receptor antagonist, sIL-1Ra) cytokines in monocytes (212). One provocative finding is that TNF and IL- $1 \beta$ production, unlike sIL-1Ra, is inhibited by high-density lipoproteins (HDL) (212). More recently, Carpintero et al. (213) reached an analogous conclusion by demonstrating that HDL inhibit T-cell MV-induced proinflammatory protein secretion by monocytes. Follow-up experiments (214-216) were designed to test the ability of T-cell generated MVs to activate mast cells (MCs). The first study that addresses this question indeed shows that T-cell generated MVs can initiate degranulation and cytokine (IL-8, oncostatin M) release from MCs (214). Attention should also be drawn to the new observation that T-cell generated MVs provoke MCs to produce IL-24 (215). Moreover, it appears that MC activation depends on miR-4443 provided by T-cell generated MVs (216). The main consequence of miR-4443 internalization into $\mathrm{MCs}$ is therefore to downregulate the protein tyrosine phosphatase receptor type J (PTPRJ) gene expression, leading to increased extracellular signal-regulated kinase (ERK) phosphorylation, and heightened release of IL-8 (216). Moreover, there is substantial evidence that T-cell generated MVs are involved in endothelial dysfunction, which was documented by Martin et al. (217) and Mostefai et al. (218). These authors postulated that T-cell generated MVs decrease
NO production at the same time increasing ROS production in endothelial cells $(217,218)$. Based on the fact that T-cell generated MVs may interact with different cells, Qiu et al. (219) recognized them as the first to move in the proinflammatory cytokine release by bronchial epithelial cells (BECs). Other than describing MVs originating from $\mathrm{T}$ lymphocytes in terms of their direct inflammatory action, studies by Qui's team also proved that these MVs promote apoptosis of normal cells (BECs) $(219,220)$ and cancer cells (retinoblastoma cells) (221). Second, increased amounts of circulating T-cell generated MVs were found in patients with active chronic hepatitis C $(222,223)$. High levels of these MVs in blood were associated with disease severity (223) as most likely resulting from excessive fibrolytic activity of hepatic stellate cells (HSCs) after their fusion with MVs (222). Third, non-infectious inflammatory diseases also elevate blood lymphocyte MV levels. A striking increase in the levels of T/B lymphocyte MVs was apparent in polymyositis/dermatomyositis (67), systemic lupus erythematosus (224), rheumatoid arthritis (225) and non-alcoholic fatty liver disease (223). It is interesting that levels of B-cell derived MVs were significantly lower in multiple sclerosis patients than in healthy controls, although clinical importance of this phenomenon is unknown (226).

All the findings add to the conclusion that MVs released from leukocytes show multidirectional actions during the response of immune system. Their primary function appears to consist in the activation of proinflammatory response in other cell types. Their

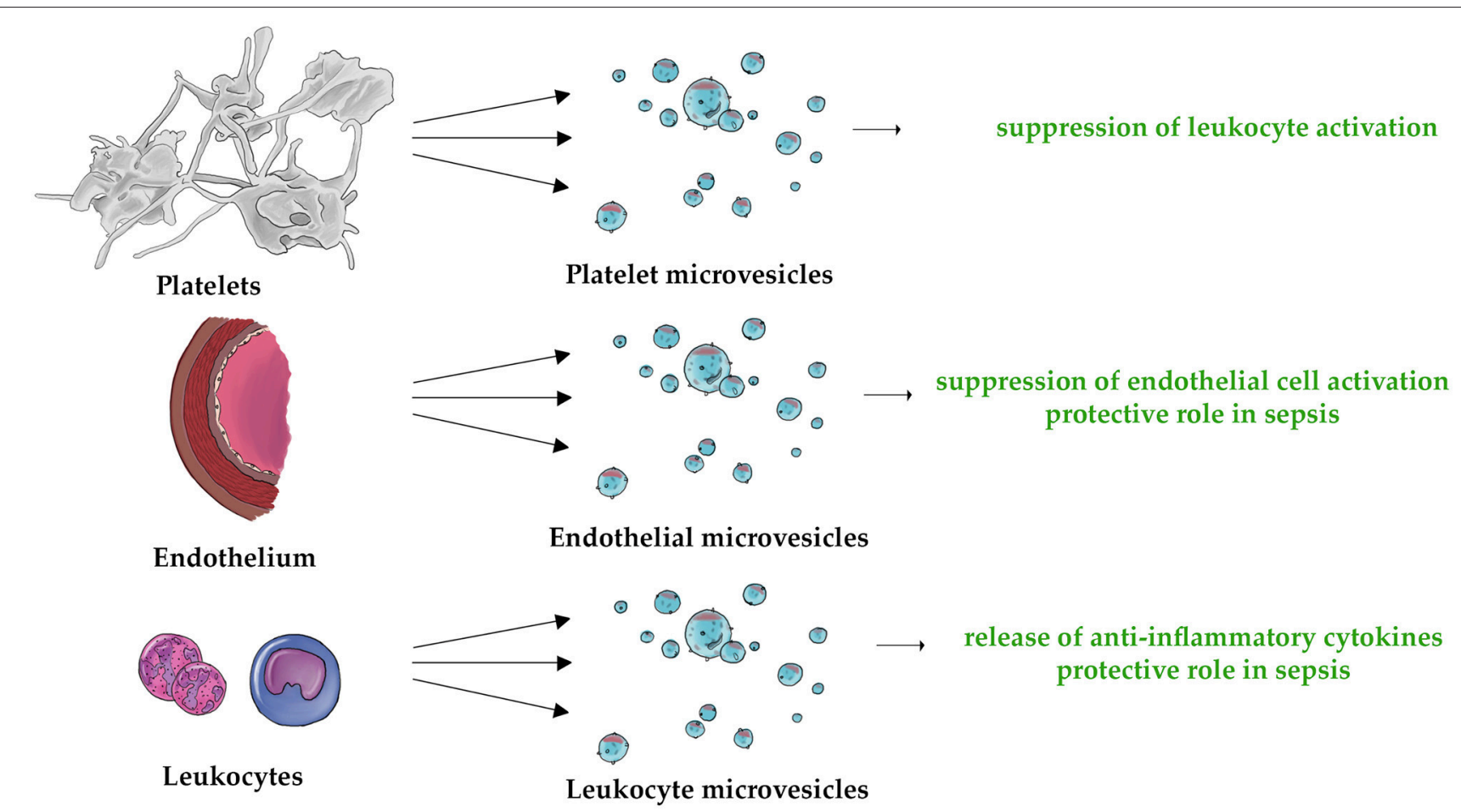

FIGURE 3 | The three types of MVs (PMVs, EMVs, and LMVs) are characterized by their unique anti-inflammatory properties. This applies to the following mechanisms: suppression of leukocyte activation (132, 135), suppression of endothelial cell activation (155), protective role in sepsis (170, 171, 204), and release of anti-inflammatory cytokines $(209,210,212)$. 
role in inflammation is also emphasized by studies showing their increased generation in infectious and inflammatory diseases.

\section{EXOSOMES IN INFLAMMATION-A BRIEF PRESENTATION}

The major goal of this paper is to explain the relationship between MVs and inflammation. However, it would certainly be interesting to know whether inflammatory reactions are affected by exosomes. Researches on this issue usually focus on the specific exosomal cargo and generally confirm proinflammatory and anti-inflammatory role of exosomes. First, exosomes enhance local and systemic inflammation due to the fact that they are sources of proinflammatory cytokines themselves and may also stimulate their production in different cells. These cytokines include proteins with recognized potent proinflammatory properties: TNF $\alpha$, IL-6, IL-1 $\beta$, IL-8, CXCL1 (cytokine-induced neutrophil chemoattractant $1, \mathrm{CINC}-1)$, CCL2, $\mathrm{PGE}_{2}$, and enzymes for leukotriene synthesis (227-232). Second, exosomes may induce migration of granulocyte into inflamed tissues (232, 233) and promote inflammatory pathways in subsequent cells $(20,234)$. Third, in vitro and in vivo experiments demonstrated that exosomes induce $\mathrm{B}$ and $\mathrm{T}$ cells activation and proliferation (235-238).

Notably, currently available data strongly indicates that miRNAs associated with exosomes contributes to controlling inflammatory processes. A wide variety of miRNAs in exosomes was identified, however, they may have opposing roles in regulating inflammation (239): enhancing $(240,241)$ or suppressing inflammatory reactions (242-244). On this point, it is worth mentioning that exosomes released by cancer cells also have dual nature. Practically, these exosomes can promote and inhibit immune responses during cancer development and progression (245). One of the more intriguing aspects are also observations that systemic administration of exosomes suppress inflammation in animal models of diseases (246-249) and it is promising to use exosomes in regenerative medicine (250). Consequently, they may be a strategy in the treatment of inflammatory-associated disorder.

\section{CONCLUSION}

Overall, our review strongly suggests that MVs may function as strong regulator of both innate and adaptive immune systems. Figure 2 demonstrates schematically the universal pro- and anti-inflammatory properties of PMVs, EMVs, and LMVs. The unique anti-inflammatory properties of these MVs are also shown in Figure 3. Undoubtedly, elucidation of MV functions contributes to better understanding of the complexity of inflammatory response. While studies discussed in this paper describe the importance of MVs in immunity, they also leave some significant questions unanswered.

\section{MVs-A New Paradox in Medicine?}

Several observations indicate that MVs have paradoxical effects. They are known to coordinate significant physiological properties of tissues such as regeneration, remodeling, angiogenesis, and healing $(251,252)$ and may protect parental cells from lysis (253) and apoptosis (254). MVs have the ability to intensify and inhibit inflammatory processes. Concentrated researches on proinflammatory effects of MVs, especially of platelets origin, supplement current knowledge on the role of platelets in inflammation (255). Increased number of circulating MVs is a pathogenetic feature of many inflammatory diseases, which encourages researchers to explore the mechanisms of their influence on inflammation. Another example of the MVs paradox is their participation in hemostasis. Supposedly, the role of PMVs in the generation of blood hypercoagulability is well-established (256), however PMVs also exhibit anticoagulant properties (97) and bleeding results in reducing their release $(257,258)$. Thus, it seems that multiplicity of functions of MVs under various physiological and pathological conditions is immense and depends on specific cargo and factor stimulating their release. Hence, it is impossible to unambiguously classify MVs as beneficial or harmful structures.

\section{Other MV Types in Inflammation-A Brief Presentation}

The interaction between numerous MV types such as red blood cells MVs (RMVs), liver MVs (hepatic MVs, HMVs), central nervous system MVs (brain MVs, BMVs), and inflammation was demonstrated by laboratory and clinical analyses. RMV forms present in both red blood cell concentrates and circulation, which some authors (259) consider to be the earliest described among all the MVs types (260), can act in a pro- and anti-inflammatory way (261-263). The liver, an organ lacking uniform histological structure (264), is able to release MVs form hepatocytes (75), cholangiocytes (265), stellate cells (265), stem cells (266), and cancer cells (267). Fundamentally, EVs released by liver cells are strongly proinflammatory (268-271). On the contrary, it was also shown that HMVs protect hepatocytes from injury (272) and induce the regeneration of parental cells (266). Populations of MVs released by CNS cells are relatively rarely studied, nevertheless, few investigations have yielded conclusions that microglia and astrocytes derived MVs carry proinflammatory IL$1 \beta(273,274)$. Opposing conclusions reached in other papers accentuate that brain MVs activate protective mechanisms in multiple sclerosis (275) and stroke (276).

\section{Diagnostic Potential of MVs}

One critical and yet unresolved problem is the diagnostic potential of MVs in inflammatory disorders. MVs as marker for diagnosis or treatment monitoring was tested by many authors, especially in cardiovascular disorders (277) and cancer (278). Currently, many researchers define MVs, and also exosomes, as a "liquid biopsy," which means that they can be an alternative to a classic biopsy, characterized by various limitations (278). On the other hand, however, until a precise, fast and cheap analytical method is developed, the use of MVs as a biomarker will remain fairly uncommon. One of the most widely used analytical methods for quantifying MVs levels and markers is flow cytometry (279). There are many different analytical methods used in MVs studies, such as electron 
microscopy (280), nanoparticle tracking analysis (280), western blot (280), dynamic light scattering (281), and enzyme-linked immunosorbent assay (282), however none of them is currently used in routine diagnostics. The vast majority of methods require special preparation of biological material samples and specialized equipment (283). In addition, recently developed sensitive and specific methods have not been yet established in the routine diagnosis yet (284). Certainly, there is an urging necessity to develop a technique that can be used in everyday clinical practice, which remains a high priority in the scope of medical care.

\section{MVs as Drug Delivery System}

With regard to the potential use of MVs as therapeutic agents, it is realistic to expect that MVs will be exploited as a pharmacological option themselves or will prevent the development of diseases complications. Moreover, they can also be a platform for drug transport. Multidirectional actions of specific MVs cargo make that researchers deliberate over how specific therapy affects the release of MVs. Nevertheless, more evidence is obtained to confirm that predominantly exosomes perform cardinal role of therapeutic tolls, particularly in the context of anti-inflammatory $(285,286)$, and anticancer activity $(287,288)$, and are also beneficial in the treatment of CNS disorders $(289,290)$. Moreover, the results of clinical trials showed exosomes to be useful in treating cancers (291-293). Out of all the links between MVs and their clinical use, the interaction between MVs and cancer cells is the best documented one $(294,295)$. For example, a study by Tang et al. (294) showed that tumor cells incubated with chemotherapeutic

\section{REFERENCES}

1. Chargaff E, West R. The biological significance of the thromboplastic protein of blood. J Biol Chem. (1946) 166:189-97.

2. Wolf $\mathrm{P}$. The nature and significance of platelet products in human plasma. Br J Haematol. (1967) 13:269-88. doi: 10.1111/j.1365-2141.1967.tb08741.x

3. Trams EG, Lauter CJ, Salem N Jr, Heine U. Exfoliation of membrane ecto-enzymes in the form of micro-vesicles. Biochim Biophys Acta. (1981) 645:63-70. doi: 10.1016/0005-2736(81)90512-5

4. Johnstone RM, Adam M, Hammond JR, Orr L, Turbide C. Vesicle formation during reticulocyte maturation. Association of plasma membrane activities with released vesicles (exosomes). J Biol Chem. (1987) 262:9412-20.

5. Johnstone RM, Bianchini A, Teng K. Reticulocyte maturation and exosome release: transferrin receptor containing exosomes shows multiple plasma membrane functions. Blood (1989) 74:1844-51.

6. Johnstone RM, Mathew A, Mason AB, Teng K. Exosome formation during maturation of mammalian and avian reticulocytes: evidence that exosome release is a major route for externalization of obsolete membrane proteins. $J$ Cell Physiol. (1991) 147:27-36. doi: 10.1002/jcp.1041470105

7. Gould SJ, Raposo G. As we wait: coping with an imperfect nomenclature for extracellular vesicles. J Extracell Vesicles (2013) 2:20389. doi: 10.3402/jev.v2i0.20389

8. Lötvall J, Hill AF, Hochberg F, Buzás EI, Di Vizio D, Gardiner C, et al. Minimal experimental requirements for definition of extracellular vesicles and their functions: a position statement from the international society for extracellular vesicles. J Extracell Vesicles (2014) 3:26913. doi: 10.3402/jev.v3.26913

9. Witwer KW, Soekmadji C, Hill AF, Wauben MH, Buzás EI, Di Vizio D, et al. Updating the MISEV minimal requirements for extracellular vesicle studies: drugs are likely to secrete MVs connected with drugs which are able to kill other tumor cells, but without side typical effects occurring when drugs are used alone. MVs can likewise deliver suicide mRNA/protein to cancer cells leading to tumor regression (295). Undeniably, more research evaluating such properties is necessary to provide evidence-based tools for cancer treatment.

\section{AUTHOR CONTRIBUTIONS}

AS performed literature search, wrote the manuscript, prepared tables, and designed figures. VL-K and EZ supervised and critically read the manuscript. SU and MK developed the concept of the manuscript, supervised, and critically read the manuscript and designed figures.

\section{FUNDING}

This paper was supported by the Alexander von Humboldt Foundation, Sofja Kovalevskaja Award 2012 and by the German Research Fundation (DFG) to VL-K (LU2061/4-1), by the Deutsche Krebshilfe (111184) and the DFG to MK (KO4103/4-1) and by MINIATURA 2 grant from the National Science Center to $\operatorname{AS}(2018 / 02 / \mathrm{X} / \mathrm{NZ} 5 / 00243)$.

\section{ACKNOWLEDGMENTS}

We are remarkably grateful to David Revoy (www.davidrevoy. com) for assistance with Figures.

building bridges to reproducibility. J Extracell Vesicles (2017) 6:1396823. doi: 10.1080/20013078.2017.1396823

10. DeLeo AM, Ikezu T. Extracellular vesicle biology in Alzheimer's disease and related tauopathy. J Neuroimmune Pharmaco.l (2017) 13:292-308. doi: 10.1007/s11481-017-9768-z.

11. Tetta C, Ghigo E, Silengo L, Deregibus MC, Camussi G. Extracellular vesicles as an emerging mechanism of cell-to-cell communication. Endocrine (2013) 44:11-9. doi: 10.1007/s12020-012-9839-0

12. Keerthikumar S, Chisanga D, Ariyaratne D, Al Saffar H, Anand S, Zhao K, et al. ExoCarta: a web-based compendium of exosomal cargo. J Mol Biol. (2016) 428:688-92. doi: 10.1016/j.jmb.2015.09.019

13. Kim DK, Lee J, Simpson RJ, Lötvall J, Gho YS. EVpedia: a community web resource for prokaryotic and eukaryotic extracellular vesicles research. Semin Cell Dev Biol. (2015) 40:4-7. doi: 10.1016/j.semcdb.2015. 02.005

14. Kalra H, Simpson RJ, Ji H, Aikawa E, Altevogt P, Askenase P, et al. Vesiclepedia: a compendium for extracellular vesicles with continuous community annotation. PLoS Biol. (2012) 10:1001450. doi: 10.1371/journal.pbio.1001450

15. Mateescu B, Kowal EJ, van Balkom BW, Bartel S, Bhattacharyya SN, Buzás EI, et al. Obstacles and opportunities in the functional analysis of extracellular vesicle RNA - an ISEV position paper. J Extracell Vesicles (2017) 6:1286095. doi: 10.1080/20013078.2017.1286095

16. van der Pol E, Böing AN, Harrison P, Sturk A, Nieuwland R. Classification, functions, and clinical relevance of extracellular vesicles. Pharmacol Rev. (2012) 64:676-705. doi: 10.1124/pr.112.005983

17. Raposo G, Stoorvogel W. Extracellular vesicles: exosomes, microvesicles, and friends. J Cell Biol. (2013) 200:373-83. doi: 10.1083/jcb.2012 11138 
18. Heijnen HF, Schiel AE, Fijnheer R, Geuze HJ, Sixma JJ. Activated platelets release two types of membrane vesicles: microvesicles by surface shedding and exosomes derived from exocytosis of multivesicular bodies and alphagranules. Blood (1999) 94:3791-9.

19. Raposo G, Nijman HW, Stoorvogel W, Liejendekker R, Harding CV, Melief CJ, et al. B lymphocytes secrete antigen-presenting vesicles. J Exp Med. (1996) 183:1161-72. doi: 10.1084/jem.183.3.1161

20. Tang N, Sun B, Gupta A, Rempel H, Pulliam L. Monocyte exosomes induce adhesion molecules and cytokines via activation of NF- $\kappa \mathrm{B}$ in endothelial cells. FASEB J. (2016) 30:3097-106. doi: 10.1096/fj.201600368RR

21. Vargas A, Roux-Dalvai F, Droit A, Lavoie JP. Neutrophil-derived exosomes: a new mechanism contributing to airway smooth muscle remodeling. Am J Respir Cell Mol Biol. (2016) 55:450-61. doi: 10.1165/rcmb.2016-0033OC

22. Mazzeo C, Cañas JA, Zafra MP, Rojas Marco A, Fernández-Nieto M, Sanz V, et al. Exosome secretion by eosinophils: a possible role in asthma pathogenesis. J Allergy Clin Immunol. (2015) 135:1603-13. doi: 10.1016/j.jaci.2014.11.026

23. Potolicchio I, Carven GJ, Xu X, Stipp C, Riese RJ, Stern LJ, et al. Proteomic analysis of microglia-derived exosomes: metabolic role of the aminopeptidase CD13 in neuropeptide catabolism. J Immunol. (2005) 175:2237-43. doi: 10.4049/jimmunol.175.4.2237

24. Krämer-Albers EM, Bretz N, Tenzer S, Winterstein C, Möbius W, Berger $\mathrm{H}$, et al. Oligodendrocytes secrete exosomes containing major myelin and stress-protective proteins: trophic support for axons? Proteomics Clin Appl. (2007) 1:1446-61. doi: 10.1002/prca.200700522

25. Fauré J, Lachenal G, Court M, Hirrlinger J, Chatellard-Causse C, Blot B, et al. Exosomes are released by cultured cortical neurones. Mol Cell Neurosci. (2006) 31:642-8. doi: 10.1016/j.mcn.2005.12.003

26. Taylor AR, Robinson MB, Gifondorwa DJ, Tytell M, Milligan CE. Regulation of heat shock protein 70 release in astrocytes: role of signaling kinases. Dev Neurobiol. (2007) 67:1815-29. doi: 10.1002/dneu.20559

27. Gao W, Liu H, Yuan J, Wu C, Huang D, Ma Y, et al. Exosomes derived from mature dendritic cells increase endothelial inflammation and atherosclerosis via membrane TNF- $\alpha$ mediated NF-кB pathway. J Cell Mol Med. (2016) 20:2318-27. doi: 10.1111/jcmm.12923

28. Sobo-Vujanovic A, Munich S, Vujanovic NL. Dendritic-cell exosomes crosspresent toll-like receptor-ligands and activate bystander dendritic cells. Cell Immunol. (2014) 289:119-27. doi: 10.1016/j.cellimm.2014.03.016

29. Koeck ES, Iordanskaia T, Sevilla S, Ferrante SC, Hubal MJ, Freishtat RJ, et al. Adipocyte exosomes induce transforming growth factor beta pathway dysregulation in hepatocytes: a novel paradigm for obesity-related liver disease. J Surg Res. (2014) 192:268-75. doi: 10.1016/j.jss.2014.06.050

30. Wang J, Wu Y, Guo J, Fei X, Yu L, Ma S. Adipocyte-derived exosomes promote lung cancer metastasis by increasing MMP9 activity via transferring MMP3 to lung cancer cells. Oncotarget (2017) 8:81880-91. doi: 10.18632/oncotarget.18737

31. Ekström K, Valadi H, Sjöstrand M, Malmhäll C, Bossios A, Eldh M, et al. Characterization of mRNA and microRNA in human mast cell-derived exosomes and their transfer to other mast cells and blood CD34 progenitor cells. J Extracell Vesicles (2012) 1:18389. doi: 10.3402/jev.v1i0.18389

32. Veerappan A, Thompson M, Savage AR, Silverman ML, Chan WS, Sung B, et al. Mast cells and exosomes in hyperoxia-induced neonatal lung disease. Am J Physiol Lung Cell Mol Physiol. (2016) 310:1218-32. doi: 10.1152/ajplung.00299.2015

33. Zhang YZ, Liu F, Song CG, Cao XL, Zhang YF, Wu HN, et al. Exosomes derived from human umbilical vein endothelial cells promote neural stem cell expansion while maintain their stemness in culture. Biochem Biophys Res Commun. (2018) 495:892-8. doi: 10.1016/j.bbrc.2017.11.092

34. Wang J, Guo R, Yang Y, Jacobs B, Chen S, Iwuchukwu I, et al. The novel methods for analysis of exosomes released from endothelial cells and endothelial progenitor cells. Stem Cells Int. (2016) 2016:2639728. doi: $10.1155 / 2016 / 2639728$

35. Conde-Vancells J, Rodriguez-Suarez E, Embade N, Gil D, Matthiesen R, Valle $\mathrm{M}$, et al. Characterization and comprehensive proteome profiling of exosomes secreted by hepatocytes. J Proteome Res. (2008) 7:5157-66. doi: $10.1021 /$ pr8004887

36. van Niel G, Raposo G, Candalh C, Boussac M, Hershberg R, CerfBensussan $\mathrm{N}$, et al. Intestinal epithelial cells secrete exosome-like vesicles. Gastroenterology (2001) 121:337-49. doi: 10.1053/gast.2001 26263

37. Garcia NA, Moncayo-Arlandi J, Sepulveda P, Diez-Juan A. Cardiomyocyte exosomes regulate glycolytic flux in endothelium by direct transfer of GLUT transporters and glycolytic enzymes. Cardiovasc Res. (2016) 109:397-408. doi: $10.1093 / \mathrm{cvr} / \mathrm{cvv} 260$

38. Caby MP, Lankar D, Vincendeau-Scherrer C, Raposo G, Bonnerot C. Exosomal-like vesicles are present in human blood plasma. Int Immunol. (2005) 17:879-87. doi: 10.1093/intimm/dxh267

39. Pisitkun T, Shen RF, Knepper MA. Identification and proteomic profiling of exosomes in human urine. Proc Natl Acad Sci USA (2004) 101:13368-73. doi: 10.1073/pnas.0403453101

40. Yagi Y, Ohkubo T, Kawaji H, Machida A, Miyata H, Goda S, et al. Nextgeneration sequencing-based small RNA profiling of cerebrospinal fluid exosomes. Neurosci Lett. (2017) 636:48-57. doi: 10.1016/j.neulet.2016.10.042

41. Michael A, Bajracharya SD, Yuen PS, Zhou H, Star RA, Illei GG, et al. Exosomes from human saliva as a source of microRNA biomarkers. Oral Dis. (2010) 16:34-8. doi: 10.1111/j.1601-0825.2009.01604.x

42. Admyre C, Johansson SM, Qazi KR, Filén JJ, Lahesmaa R, Norman M, et al. Exosomes with immune modulatory features are present in human breast milk. J Immunol. (2007) 179:1969-78. doi: 10.4049/jimmunol.179.3.1969

43. Wu CX, Liu ZF. Proteomic profiling of sweat exosome suggests its involvement in skin immunity. J Invest Dermatol. (2018) 138:89-97. doi: $10.1016 /$ j.jid.2017.05.040

44. Grigor'eva AE, Tamkovich SN, Eremina AV, Tupikin AE, Kabilov MR, Chernykh VV, et al. Exosomes in tears of healthy individuals: isolation, identification, and characterization. Biochem Suppl B Biomed Chem. (2016) 10:165-72.

45. Vojtech L, Woo S, Hughes S, Levy C, Ballweber L, Sauteraud RP, et al. Exosomes in human semen carry a distinctive repertoire of small noncoding RNAs with potential regulatory functions. Nucleic Acids Res. (2014) 42:7290-304. doi: 10.1093/nar/gku347

46. Asea A, Jean-Pierre C, Kaur P, Rao P, Linhares IM, Skupski D, et al. Heat shock protein-containing exosomes in mid-trimester amniotic fluids. J Reprod Immunol. (2008) 79:12-7. doi: 10.1016/j.jri.2008.06.001

47. Koga Y, Yasunaga M, Moriya Y, Akasu T, Fujita S, Yamamoto S, et al. Exosome can prevent RNase from degrading microRNA in feces. J Gastrointest Oncol. (2011) 2:215-22. doi: 10.3978/j.issn.2078-6891.2011.015

48. Masyuk AI, Huang BQ, Ward CJ, Gradilone SA, Banales JM, Masyuk TV, et al. Biliary exosomes influence cholangiocyte regulatory mechanisms and proliferation through interaction with primary cilia. Am J Physiol Gastrointest Liver Physiol. (2010) 299:990-9. doi: 10.1152/ajpgi.00093.2010

49. Dismuke WM, Challa P, Navarro I, Stamer WD, Liu Y. Human aqueous humor exosomes. Exp Eye Res. (2015) 132:73-7. doi: 10.1016/j.exer.2015.01.019

50. Ragusa M, Barbagallo C, Statello L, Caltabiano R, Russo A, Puzzo L, et al. miRNA profiling in vitreous humor, vitreal exosomes and serum from uveal melanoma patients: pathological and diagnostic implications. Cancer Biol Ther. (2015) 16:1387-96. doi: 10.1080/15384047.2015.1046021

51. Kolhe R, Hunter M, Liu S, Jadeja RN, Pundkar C, Mondal AK, et al. Gender-specific differential expression of exosomal miRNA in synovial fluid of patients with osteoarthritis. Sci Rep. (2017) 7:2029. doi: 10.1038/s41598-017-01905-y

52. Beltrami C, Besnier M, Shantikumar S, Shearn AI, Rajakaruna C, Laftah A, et al. Human pericardial fluid contains exosomes enriched with cardiovascular-expressed microRNAs and promotes therapeutic angiogenesis. Mol Ther. (2017) 25:679-93. doi: 10.1016/j.ymthe.2016.12.022

53. Soung YH, Ford S, Zhang V, Chung J. Exosomes in cancer diagnostics. Cancers (Basel) (2017) 9:8. doi: 10.3390/cancers9010008

54. Pan BT, Teng K, Wu C, Adam M, Johnstone RM. Electron microscopic evidence for externalization of the transferrin receptor in vesicular form in sheep reticulocytes. J Cell Biol. (1985) 101:942-8. doi: 10.1083/jcb.101.3.942

55. Clague MJ Urbé S. Multivesicular bodies. Curr Biol. (2008) 18:402-4. doi: 10.1016/j.cub.2008.02.068

56. Booth AM, Fang Y, Fallon JK, Yang JM, Hildreth JE, Gould SJ. Exosomes and HIV gag bud from endosome-like domains of the T cell plasma membrane. J Cell Biol. (2006) 172:923-35. doi: 10.1083/jcb.2005 08014 
57. Colombo M, Moita C, van Niel G, Kowal J, Vigneron J, Benaroch P, et al. Analysis of ESCRT functions in exosome biogenesis, composition and secretion highlights the heterogeneity of extracellular vesicles. J Cell Sci. (2013) 126:5553-65. doi: 10.1242/jcs.128868

58. Stuffers S, Sem Wegner C, Stenmark H, Brech A. Multivesicular endosome biogenesis in the absence of ESCRTs. Traffic (2009) 10:925-37. doi: 10.1111/j.1600-0854.2009.00920.x

59. Andreu Z, Yáñez-Mó M. Tetraspanins in extracellular vesicle formation and function. Front Immunol. (2014) 5:442. doi: 10.3389/fimmu.2014.00442

60. Valadi H, Ekström K, Bossios A, Sjöstrand M, Lee JJ, Lötvall JO. Exosome-mediated transfer of mRNAs and microRNAs is a novel mechanism of genetic exchange between cells. Nat Cell Biol. (2007) 9:654-9. doi: $10.1038 /$ ncb1596

61. Tkach M, Kowal J, Théry C. Why the need and how to approach the functional diversity of extracellular vesicles. Philos Trans $R$ Soc Lond B Biol Sci. (2018) 373:20160479. doi: 10.1098/rstb.2016.0479

62. Stahl PD, Raposo G. Exosomes and extracellular vesicles: the path forward. Essays Biochem. (2018) 62:119-24. doi: 10.1042/EBC20170088

63. Shet AS, Aras O, Gupta K, Hass MJ, Rausch DJ, Saba N, et al. Sickle blood contains tissue factor-positive microparticles derived from endothelial cells and monocytes. Blood (2003) 102:2678-83. doi: 10.1182/blood-2003-03-0693

64. Connor DE, Exner T, Ma DD, Joseph JE. The majority of circulating plateletderived microparticles fail to bind annexin V, lack phospholipid-dependent procoagulant activity and demonstrate greater expression of glycoprotein $\mathrm{Ib}$. Thromb Haemost. (2010) 103:1044-52. doi: 10.1160/TH09-09-0644

65. Canellini G, Rubin O, Delobel J, Crettaz D, Lion N, Tissot JD. Red blood cell microparticles and blood group antigens: an analysis by flow cytometry. Blood Transfus. (2012) 10:39-45. doi: 10.2450/2012.007S

66. Pitanga TN, de Aragão França L, Rocha VC, Meirelles T, Borges VM, Gonçalves MS, et al. Neutrophil-derived microparticles induce myeloperoxidase-mediated damage of vascular endothelial cells. BMC Cell Biol. (2014) 15:21. doi: 10.1186/1471-2121-15-21

67. Baka Z, Senolt L, Vencovsky J, Mann H, Simon PS, Kittel A, et al. Increased serum concentration of immune cell derived microparticles in polymyositis/dermatomyositis. Immunol Lett. (2010) 128:124-30. doi: 10.1016/j.imlet.2009.12.018

68. Kumar A, Stoica BA, Loane DJ, Yang M, Abulwerdi G, Khan N, et al. Microglial-derived microparticles mediate neuroinflammation after traumatic brain injury. J Neuroinflammation (2017) 14:47. doi: 10.1186/s12974-017-0819-4

69. Tian Y, Salsbery B, Wang M, Yuan H, Yang J, Zhao Z, et al. Brain-derived microparticles induce systemic coagulation in a murine model of traumatic brain injury. Blood (2015) 125:2151-9. doi: 10.1182/blood-2014-09-598805

70. Wahlund CJE, Güclüler G, Hiltbrunner S, Veerman RE, Näslund TI, Gabrielsson S. Exosomes from antigen-pulsed dendritic cells induce stronger antigen-specific immune responses than microvesicles in vivo. Sci Rep. (2017) 7:17095. doi: 10.1038/s41598-017-16609-6

71. Eguchi A, Mulya A, Lazic M, Radhakrishnan D, Berk MP, Povero $\mathrm{D}$, et al. Microparticles release by adipocytes act as "find-me" signals to promote macrophage migration. PLOS ONE (2015) 10:0123110. doi: 10.1371/journal.pone.0123110

72. Combes V, Simon AC, Grau GE, Arnoux D, Camoin L, Sabatier F, et al. In vitro generation of endothelial microparticles and possible prothrombotic activity in patients with lupus anticoagulant. J Clin Invest. (1999) 104:93-102. doi: 10.1172/JCI4985

73. Wheway J, Latham SL, Combes V, Grau GE. Endothelial microparticles interact with and support the proliferation of T cells. J Immunol. (2014) 193:3378-87. doi: 10.4049/jimmunol.1303431

74. Deregibus MC, Cantaluppi V, Calogero R, Lo Iacono M, Tetta C, Biancone L, et al. Endothelial progenitor cell derived microvesicles activate an angiogenic program in endothelial cells by a horizontal transfer of mRNA. Blood (2007) 110:2440-8. doi: 10.1182/blood-2007-03-078709

75. Povero D, Eguchi A, Niesman IR, Andronikou N, de Mollerat du Jeu X, Mulya A, et al. Lipid-induced toxicity stimulates hepatocytes to release angiogenic microparticles that require Vanin-1 for uptake by endothelial cells. Sci Signal (2013) 6:88. doi: 10.1126/scisignal.2004512

76. Chahed S, Leroyer AS, Benzerroug M, Gaucher D, Georgescu A, Picaud S, et al. Increased vitreous shedding of microparticles in proliferative diabetic retinopathy stimulates endothelial proliferation. Diabetes (2010) 59:694-701 doi: $10.2337 / \mathrm{db} 08-1524$

77. Uszynski M, Zekanowska E, Uszynski W, Kuczynski J, Zylinski A. Microparticles (MPs), tissue factor (TF) and tissue factor inhibitor (TFPI) in cord blood plasma. A preliminary study and literature survey of procoagulant properties of MPs. Eur J Obstet Gynecol Reprod Biol. (2011) 158:37-41. doi: 10.1016/j.ejogrb.2011.04.026

78. Viñuela-Berni V, Doníz-Padilla L, Figueroa-Vega N, Portillo-Salazar H, Abud-Mendoza C, Baranda L, et al. Proportions of several types of plasma and urine microparticles are increased in patients with rheumatoid arthritis with active disease. Clin Exp Immunol. (2015) 180:442-51. doi: $10.1111 /$ cei. 12598

79. Mobarrez F, Nybom R, Johansson V, Hultman CM, Wallén H, Landén M, et al. Microparticles and microscopic structures in three fractions of fresh cerebrospinal fluid in schizophrenia: case report of twins. Schizophr Res. (2013) 143:192-7. doi: 10.1016/j.schres.2012.10.030.

80. Berckmans RJ, Sturk A, van Tienen LM, Schaap MC, Nieuwland R. Cellderived vesicles exposing coagulant tissue factor in saliva. Blood (2011) 117:3172-80. doi: 10.1182/blood-2010-06-290460

81. Uszynski W, Zekanowska E, Uszynski M, Zylinski A, Kuczynski J. New observations on procoagulant properties of amniotic fluid: microparticles (MPs) and tissue factor-bearing MPs (MPs-TF), comparison with maternal blood plasma. Thromb Res. (2013) 132:757-60. doi: 10.1016/j.thromres.2013.10.001

82. Berckmans RJ, Nieuwland R, Kraan MC, Schaap MC, Pots D, Smeets TJ, et al. Synovial microparticles from arthritic patients modulate chemokine and cytokine release by synoviocytes. Arthritis Res Ther. (2005) 7:536-44. doi: 10.1186/ar1706

83. Guervilly C, Lacroix R, Forel JM, Roch A, Camoin-Jau L, Papazian L, et al. High levels of circulating leukocyte microparticles are associated with better outcome in acute respiratory distress syndrome. Crit Care. (2011) 15:31. doi: $10.1186 /$ cc9978

84. Mrvar-Brecko A, Sustar V, Jansa V, Stukelj R, Jansa R, Mujagić E, et al. Isolated microvesicles from peripheral blood and body fluids as observed by scanning electron microscope. Blood Cells Mol Dis. (2010) 44:307-12. doi: 10.1016/j.bcmd.2010.02.003

85. Rautou PE, Leroyer AS, Ramkhelawon B, Devue C, Duflaut D, Vion AC, et al. Microparticles from human atherosclerotic plaques promote endothelial ICAM-1-dependent monocyte adhesion and transendothelial migration. Circ Res. (2011) 108:335-43. doi: 10.1161/CIRCRESAHA.110. 237420

86. Jimenez JJ, Jy W, Mauro LM, Soderland C, Horstman LL, Ahn YS. Endothelial cells release phenotypically and quantitatively distinct microparticles in activation and apoptosis. Thromb Res. (2003) 109:175-80. doi: 10.1016/S0049-3848(03)00064-1

87. Shai E, Rosa I, Parguiña AF, Motahedeh S, Varon D, García Á. Comparative analysis of platelet-derived microparticles reveals differences in their amount and proteome depending on the platelet stimulus. J Proteomics (2012) 76:287-96. doi: 10.1016/j.jprot.2012. 02.030

88. Bernimoulin M, Waters EK, Foy M, Steele BM, Sullivan M, Falet $\mathrm{H}$, et al. Differential stimulation of monocytic cells results in distinct populations of microparticles. J Thromb Haemost. (2009) 7:1019-28. doi: 10.1111/j.1538-7836.2009.03434.x

89. Morel O, Jesel L, Freyssinet JM, Toti F. Cellular mechanisms underlying the formation of circulating microparticles. Arterioscler Thromb Vasc Biol. (2011) 31:15-26. doi: 10.1161/ATVBAHA.109.200956

90. van Es N, Bleker S, Sturk A, Nieuwland R. Clinical significance of tissue factor-exposing microparticles in arterial and venous thrombosis. Semin Thromb Hemost. (2015) 41:718-27. doi: 10.1055/s-0035-1556047

91. Switonska M, Słomka A, Sinkiewicz W, Zekanowska E. Tissue-factorbearing microparticles (MPs-TF) in patients with acute ischaemic stroke: the influence of stroke treatment on MPs-TF generation. Eur J Neurol. (2015) 22:395-401. doi: 10.1111/ene.12591

92. Chiva-Blanch G, Laake K, Myhre P, Bratseth V, Arnesen H, Solheim S, et al. Platelet-, monocyte-derived and tissue factor-carrying circulating microparticles are related to acute myocardial infarction severity. PLoS ONE (2017) 12:0172558. doi: 10.1371/journal.pone.0172558 
93. Hron G, Kollars M, Weber H, Sagaster V, Quehenberger P, Eichinger S, et al. Tissue factor-positive microparticles: cellular origin and association with coagulation activation in patients with colorectal cancer. Thromb Haemost. (2007) 97:119-23. doi: 10.1160/TH06-03-0141

94. Badimon L, Suades R, Arderiu G, Peña E, Chiva-Blanch G, Padró T. Microvesicles in atherosclerosis and angiogenesis: from bench to bedside and reverse. Front Cardiovasc Med. (2017) 4:77. doi: 10.3389/fcvm.2017.00077

95. Costa-Filho RC, Bozza FA. Platelets: an outlook from biology through evidence-based achievements in critical care. Ann Transl Med. (2017) 5:449. doi: 10.21037/atm.2017.11.04

96. Kornek M, Schuppan D. Microparticles: modulators and biomarkers of liver disease. J Hepatol. (2012) 57:1144-6. doi: 10.1016/j.jhep.2012.07.029

97. Berckmans RJ, Nieuwland R, Böing AN, Romijn FP, Hack CE, Sturk A. Cellderived microparticles circulate in healthy humans and support low grade thrombin generation. Thromb Haemost. (2001) 85:639-46.

98. Kailashiya J. Platelet-derived microparticles analysis: techniques, challenges and recommendations. Anal Biochem. (2018) 546:78-85. doi: 10.1016/j.ab.2018.01.030

99. Flaumenhaft R, Dilks JR, Richardson J, Alden E, Patel-Hett SR, Battinelli E, et al. Megakaryocyte-derived microparticles: direct visualization and distinction from platelet-derived microparticles. Blood (2009) 113:1112-21. doi: 10.1182/blood-2008-06-163832

100. Barry OP, Praticò D, Lawson JA, FitzGerald GA. Transcellular activation of platelets and endothelial cells by bioactive lipids in platelet microparticles. $J$ Clin Invest. (1997) 99:2118-27. doi: 10.1172/JCI119385

101. Barry OP, Praticò D, Savani RC, FitzGerald GA. Modulation of monocyteendothelial cell interactions by platelet microparticles. J Clin Invest. (1998) 102:136-44. doi: 10.1172/JCI2592

102. Smith CW, Marlin SD, Rothlein R, Toman C, Anderson DC. Cooperative interactions of LFA-1 and Mac-1 with intercellular adhesion molecule-1 in facilitating adherence and transendothelial migration of human neutrophils in vitro. J Clin Invest. (1989) 83:2008-17. doi: 10.1172/JCI114111

103. Rahman A, Fazal F. Hug tightly and say goodbye: role of endothelial ICAM1 in leukocyte transmigration. Antioxid Redox Signal (2009) 11:823-39. doi: 10.1089/ars.2008.2204

104. Mause SF, von Hundelshausen P, Zernecke A, Koenen RR, Weber C. Platelet microparticles: a transcellular delivery system for RANTES promoting monocyte recruitment on endothelium. Arterioscler Thromb Vasc Biol. (2005) 25:1512-8. doi: 10.1161/01.ATV.0000170133.43608.37

105. Forlow SB, McEver RP, Nollert MU. Leukocyte-leukocyte interactions mediated by platelet microparticles under flow. Blood (2000) 95:1317-23.

106. Brunetti M, Martelli N, Manarini S, Mascetra N, Musiani P, Cerletti C, et al. Polymorphonuclear leukocyte apoptosis is inhibited by platelet-released mediators, role of TGFbeta-1. Thromb Haemost. (2000) 84:478-83.

107. Böing AN, Hau CM, Sturk A, Nieuwland R. Platelet microparticles contain active caspase 3. Platelets (2008) 19:96-103. doi: 10.1080/09537100701777295

108. Lindemann S, Tolley ND, Dixon DA, McIntyre TM, Prescott SM, Zimmerman GA, et al. Activated platelets mediate inflammatory signaling by regulated interleukin 1beta synthesis. J Cell Biol. (2001) 154:485-90. doi: $10.1083 /$ jcb.200105058

109. Xie RF, Hu P, Wang ZC, Yang J, Yang YM, Gao L, et al. Platelet-derived microparticles induce polymorphonuclear leukocyte-mediated damage of human pulmonary microvascular endothelial cells. Transfusion (2015) 55:1051-7. doi: 10.1111/trf.12952

110. Antoniades C, Bakogiannis C, Tousoulis D, Antonopoulos AS, Stefanadis C. The CD40/CD40 ligand system: linking inflammation with atherothrombosis. J Am Coll Cardiol. (2009) 54:669-77. doi: 10.1016/j.jacc.2009.03.076

111. Dean WL, Lee MJ, Cummins TD, Schultz DJ, Powell DW. Proteomic and functional characterisation of platelet microparticle size classes. Thromb Haemost. (2009) 102:711-8. doi: 10.1160/TH09-04-243

112. Cloutier N, Tan S, Boudreau LH, Cramb C, Subbaiah R, Lahey L, et al. The exposure of autoantigens by microparticles underlies the formation of potent inflammatory components: the microparticleassociated immune complexes. EMBO Mol Med. (2013) 5:235-49. doi: $10.1002 / \mathrm{emmm} .201201846$
113. Boilard E, Nigrovic PA, Larabee K, Watts GF, Coblyn JS, Weinblatt $\mathrm{ME}$, et al. Platelets amplify inflammation in arthritis via collagendependent microparticle production. Science (2010) 327:580-3. doi: 10.1126/science.1181928

114. Balvers K, Curry N, Kleinveld DJ, Böing AN, Nieuwland R, Goslings JC, et al. Endogenous microparticles drive the proinflammatory host immune response in severely injured trauma patients. Shock (2015) 43:317-21. doi: 10.1097/SHK.0000000000000321

115. Badimon L, Suades R, Fuentes E, Palomo I, Padró T. Role of plateletderived microvesicles as crosstalk mediators in atherothrombosis and future pharmacology targets: a link between inflammation, atherosclerosis, and thrombosis. Front Pharmacol. (2016) 7:293. doi: 10.3389/fphar.2016.00293

116. Chen Y, Li G, Liu ML. Microvesicles as emerging biomarkers and therapeutic targets in cardiometabolic diseases. Genomics Proteomics Bioinformatics (2018) 16:50-62. doi: 10.1016/j.gpb.2017.03.006

117. Sprague DL, Elzey BD, Crist SA, Waldschmidt TJ, Jensen RJ, Ratliff TL. Platelet-mediated modulation of adaptive immunity: unique delivery of CD154 signal by platelet-derived membrane vesicles. Blood (2008) 111:502836. doi: 10.1182/blood-2007-06-097410

118. Yari F, Motefaker M, Nikougoftar M, Khayati Z. Interaction of plateletderived microparticles with a human B-lymphoblast cell line: a clue for the immunologic function of the microparticles. Transfus Med Hemother. (2018) 45:55-61. doi: 10.1159/000479072

119. Bei JJ, Liu C, Peng S, Liu CH, Zhao WB, Qu XL, et al. Staphylococcal SSL5induced platelet microparticles provoke proinflammatory responses via the CD40/TRAF6/NFאB signalling pathway in monocytes. Thromb Haemost. (2016) 115:632-45. doi: 10.1160/TH15-04-0322

120. Ståhl AL, Sartz L, Karpman D. Complement activation on plateletleukocyte complexes and microparticles in enterohemorrhagic Escherichia coli-induced hemolytic uremic syndrome. Blood (2011) 117:5503-13. doi: 10.1182/blood-2010-09-309161

121. Rozmyslowicz T, Majka M, Kijowski J, Murphy SL, Conover DO, Poncz M, et al. Platelet- and megakaryocyte-derived microparticles transfer CXCR4 receptor to CXCR4-null cells and make them susceptible to infection by X4-HIV. AIDS (2003) 17:33-42. doi: 10.1097/01.aids.0000042948.95433.3d

122. Corrales-Medina VF, Simkins J, Chirinos JA, Serpa JA, Horstman LL, Jy W, et al. Increased levels of platelet microparticles in HIV-infected patients with good response to highly active antiretroviral therapy. J Acquir Immune Defic Syndr. (2010) 54:217-8. doi: 10.1097/QAI.0b013e3181c8f4c9

123. Mayne E, Funderburg NT, Sieg SF, Asaad R, Kalinowska M, Rodriguez $\mathrm{B}$, et al. Increased platelet and microparticle activation in HIV infection: upregulation of P-selectin and tissue factor expression. J Acquir Immune Defic Syndr. (2012) 59:340-6. doi: 10.1097/QAI.0b013e3182439355

124. Punyadee N, Mairiang D, Thiemmeca S, Komoltri C, Pan-Ngum W, Chomanee N, et al. Microparticles provide a novel biomarker to predict severe clinical outcomes of dengue virus infection. J Virol. (2015) 89:1587607. doi: 10.1128/JVI.02207-14

125. Faille D, Combes V, Mitchell AJ, Fontaine A, Juhan-Vague I, Alessi $\mathrm{MC}$, et al. Platelet microparticles: a new player in malaria parasite cytoadherence to human brain endothelium. FASEB J. (2009) 23:3449-58. doi: 10.1096/fj.09-135822

126. Pankoui Mfonkeu JB, Gouado I, Fotso Kuaté H, Zambou O, Amvam Zollo $\mathrm{PH}, \mathrm{Grau}$ GE, et al. Elevated cell-specific microparticles are a biological marker for cerebral dysfunctions in human severe malaria. PLoS ONE (2010) 5:13415.doi: 10.1371/journal.pone.0013415

127. Campos FM, Franklin BS, Teixeira-Carvalho A, Filho AL, de Paula SC, Fontes CJ, et al. Augmented plasma microparticles during acute Plasmodium vivax infection. Malar J. (2010) 9:327. doi: 10.1186/1475-2875-9-327

128. Badimon L, Peña E, Arderiu G, Padró T, Slevin M, Vilahur G, et al. C-reactive protein in atherothrombosis and angiogenesis. Front Immunol. (2018) 9:430. doi: 10.3389/fimmu.2018.00430

129. Thiele JR, Zeller J, Bannasch H, Stark GB, Peter K, Eisenhardt SU. Targeting $\mathrm{C}$-reactive protein in inflammatory disease by preventing conformational changes. Mediators Inflamm. (2015) 2015:372432. doi: 10.1155/2015/372432

130. Braig D, Nero TL, Koch HG, Kaiser B, Wang X, Thiele JR, et al. Transitional changes in the CRP structure lead to the exposure of proinflammatory binding sites. Nat Commun. (2017) 8:14188. doi: 10.1038/ncomms14188 
131. Tang K, Liu J, Yang Z, Zhang B, Zhang H, Huang C, et al. Microparticles mediate enzyme transfer from platelets to mast cells: a new pathway for lipoxin A4 biosynthesis. Biochem Biophys Res Commun. (2010) 400:432-6. doi: 10.1016/j.bbrc.2010.08.095

132. Sadallah S, Eken C, Martin PJ, Schifferli JA. Microparticles (ectosomes) shed by stored human platelets downregulate macrophages and modify the development of dendritic cells. J Immunol. (2011) 186:6543-52. doi: 10.4049/jimmunol.1002788

133. Laffont B, Corduan A, Rousseau M, Duchez AC, Lee CH, Boilard E, et al. Platelet microparticles reprogram macrophage gene expression and function. Thromb Haemost. (2016) 115:311-23. doi: 10.1160/TH15-05-0389

134. Ceroi A, Delettre FA, Marotel C, Gauthier T, Asgarova A, Biichlé S, et al. The anti-inflammatory effects of platelet-derived microparticles in human plasmacytoid dendritic cells involve liver $\mathrm{X}$ receptor activation. Haematologica (2016) 101:72-6.doi: 10.3324/haematol.2015.135459

135. Dinkla S, van Cranenbroek B, van der Heijden WA, He X, Wallbrecher R, Dumitriu IE, et al. Platelet microparticles inhibit IL-17 production by regulatory $\mathrm{T}$ cells through P-selectin. Blood (2016) 127:1976-86. doi: 10.1182/blood-2015-04-640300

136. Goncharov NV, Nadeev AD, Jenkins RO, Avdonin PV. Markers and biomarkers of endothelium: when something is rotten in the state. Oxid Med Cell Longev. (2017) 2017:9759735. doi: 10.1155/2017/9759735

137. Deng F, Wang S, Zhang L. Endothelial microparticles act as novel diagnostic and therapeutic biomarkers of circulatory hypoxia-related diseases: a literature review. J Cell Mol Med. (2017) 21:1698-710. doi: $10.1111 /$ jcmm. 13125

138. Gelderman MP, Simak J. Flow cytometric analysis of cell membrane microparticles. Methods Mol Biol. (2008) 484:79-93. doi: 10.1007/978-1-59745-398-1_6

139. Duval A, Helley D, Capron L, Youinou P, Renaudineau Y, Dubucquoi $S$, et al. Endothelial dysfunction in systemic lupus patients with low disease activity: evaluation by quantification and characterization of circulating endothelial microparticles, role of anti-endothelial cell antibodies. Rheumatology (2010) 49:1049-55.doi: 10.1093/rheumatology/ keq041

140. Abid Hussein MN, Böing AN, Biró E, Hoek FJ, Vogel GM, Meuleman DG, et al. Phospholipid composition of in vitro endothelial microparticles and their in vivo thrombogenic properties. Thromb Res. (2008) 121:865-71. doi: 10.1016/j.thromres.2007.08.005

141. Yamamoto S, Niida S, Azuma E, Yanagibashi T, Muramatsu M, Huang TT, et al. Inflammation-induced endothelial cell-derived extracellular vesicles modulate the cellular status of pericytes. Sci Rep. (2015) 5:8505. doi: $10.1038 /$ srep08505

142. Hamilton KK, Hattori R, Esmon CT, Sims PJ. Complement proteins C5b-9 induce vesiculation of the endothelial plasma membrane and expose catalytic surface for assembly of the prothrombinase enzyme complex. J Biol Chem. (1990) 265:3809-14.

143. Wang JM, Wang Y, Huang JY, Yang Z, Chen L, Wang LC, et al. CReactive protein-induced endothelial microparticle generation in HUVECs is related to BH4-dependent NO formation. J Vasc Res. (2007) 44:241-8. doi: 10.1159/000100558

144. Alexy T, Rooney K, Weber M, Gray WD, Searles CD. TNF$\alpha$ alters the release and transfer of microparticle-encapsulated miRNAs from endothelial cells. Physiol Genomics (2014) 46:833-40. doi: 10.1152/physiolgenomics.00079.2014

145. Curtis AM, Wilkinson PF, Gui M, Gales TL, Hu E, Edelberg JM. p38 mitogen-activated protein kinase targets the production of proinflammatory endothelial microparticles. J Thromb Haemost. (2009) 7:701-9. doi: 10.1111/j.1538-7836.2009.03304.x

146. Lee SK, Yang SH, Kwon I, Lee OH, Heo JH. Role of tumour necrosis factor receptor-1 and nuclear factor- $\kappa \mathrm{B}$ in production of TNF- $\alpha$-induced proinflammatory microparticles in endothelial cells. Thromb Haemost. (2014) 112:580-8. doi: 10.1160/TH13-11-0975

147. Sabatier F, Roux V, Anfosso F, Camoin L, Sampol J, Dignat-George F. Interaction of endothelial microparticles with monocytic cells in vitro induces tissue factor-dependent procoagulant activity. Blood (2002) 99:396270. doi: 10.1182/blood.V99.11.3962
148. Ogura H, Tanaka H, Koh T, Fujita K, Fujimi S, Nakamori $\mathrm{Y}$, et al. Enhanced production of endothelial microparticles with increased binding to leukocytes in patients with severe systemic inflammatory response syndrome. J Trauma (2004) 56:823-30.doi: 10.1097/01.TA.0000084517.39244.46

149. Arteaga RB, Chirinos JA, Soriano AO, Jy W, Horstman L, Jimenez JJ, et al. Endothelial microparticles and platelet and leukocyte activation in patients with the metabolic syndrome. Am J Cardiol. (2006) 98:70-4. doi: 10.1016/j.amjcard.2006.01.054

150. Jy W, Minagar A, Jimenez JJ, Sheremata WA, Mauro LM, Horstman LL, et al. Endothelial microparticles (EMP) bind and activate monocytes: elevated EMP-monocyte conjugates in multiple sclerosis. Front Biosci. (2004) 9:313744. doi: $10.2741 / 1466$

151. Jimenez J, Jy W, Mauro LM, Horstman LL, Ahn ER, Ahn YS, et al. Elevated endothelial microparticle-monocyte complexes induced by multiple sclerosis plasma and the inhibitory effects of interferon-beta $1 \mathrm{~b}$ on release of endothelial microparticles, formation and transendothelial migration of monocyte-endothelial microparticle complexes. Mult Scler. (2005) 11:310-5. doi: 10.1191/1352458505ms1184oa

152. Liu Y, Zhang R, Qu H, Wu J, Li L, Tang Y. Endothelial microparticles activate endothelial cells to facilitate the inflammatory response. Mol Med Rep. (2017) 15:1291-6. doi: 10.3892/mmr.2017.6113

153. Yu X, Xu J, Huang G, Zhang K, Qing L, Liu W, et al. Bubble-induced endothelial microparticles promote endothelial dysfunction. PLoS ONE (2017) 12:0168881. doi: 10.1371/journal.pone.0168881

154. Nakaoka H, Hirono K, Yamamoto S, Takasaki I, Takahashi K, Kinoshita K, et al. MicroRNA-145-5p and microRNA-320a encapsulated in endothelial microparticles contribute to the progression of vasculitis in acute Kawasaki Disease. Sci Rep. (2018) 8:1016. doi: 10.1038/s41598-018-19310-4

155. Jansen F, Yang X, Baumann K, Przybilla D, Schmitz T, Flender A, et al. Endothelial microparticles reduce ICAM-1 expression in a microRNA-222-dependent mechanism. J Cell Mol Med. (2015) 19:2202-14. doi: $10.1111 /$ jcmm.12607

156. Angelot F, Seillès E, Biichlé S, Berda Y, Gaugler B, Plumas J, et al. Endothelial cell-derived microparticles induce plasmacytoid dendritic cell maturation: potential implications in inflammatory diseases. Haematologica (2009) 94:1502-12. doi: 10.3324/haematol.2009.010934

157. Chistiakov DA, Orekhov AN, Sobenin IA, Bobryshev YV. Plasmacytoid dendritic cells: development, functions, and role in atherosclerotic inflammation. Front Physiol. (2014) 5:279. doi: 10.3389/fphys.2014.00279

158. Alculumbre S, Raieli S, Hoffmann C, Chelbi R, Danlos FX, Soumelis V. Plasmacytoid pre-dendritic cells ( $\mathrm{pDC}$ ): from molecular pathways to function and disease association. Semin Cell Dev Biol. (2018). doi: 10.1016/j.semcdb.2018.02.014. [Epub ahead of print].

159. Lu Y, Li L, Yan H, Su Q, Huang J, Fu C. Endothelial microparticles exert differential effects on functions of Th1 in patients with acute coronary syndrome. Int J Cardiol. (2013) 168:5396-404. doi: 10.1016/j.ijcard.2013.08.050

160. Zhang R, Wang X, Hong M, Luo T, Zhao M, Shen H, et al. Endothelial microparticles delivering microRNA-155 into $\mathrm{T}$ lymphocytes are involved in the initiation of acute graft-versus-host disease following allogeneic hematopoietic stem cell transplantation. Oncotarget (2017) 8:23360-75. doi: 10.18632/oncotarget.15579

161. Devaraj S, Kumaresan PR, Jialal I. C-reactive protein induces release of both endothelial microparticles and circulating endothelial cells in vitro and in vivo: further evidence of endothelial dysfunction. Clin Chem. (2011) 57:1757-61. doi: 10.1373/clinchem.2011.169839

162. Habersberger J, Strang F, Scheichl A, Htun N, Bassler N, Merivirta RM, et al. Circulating microparticles generate and transport monomeric C-reactive protein in patients with myocardial infarction. Cardiovasc Res. (2012) 96:6472. doi: $10.1093 / \mathrm{cvr} / \mathrm{cvs} 237$

163. Crawford JR, Trial J, Nambi V, Hoogeveen RC, Taffet GE, Entman ML. Plasma levels of endothelial microparticles bearing monomeric C-reactive protein are increased in peripheral artery disease. J Cardiovasc Transl Res. (2016) 9:184-93. doi: 10.1007/s12265-016-9678-0

164. Cui Y, Zheng L, Jiang M, Jia R, Zhang X, Quan Q, et al. Circulating microparticles in patients with coronary heart disease and its correlation 
with interleukin-6 and C-reactive protein. Mol Biol Rep. (2013) 40:6437-42. doi: 10.1007/s11033-013-2758-1

165. Dursun I, Poyrazoglu HM, Gunduz Z, Ulger H, Yykylmaz A, Dusunsel R, et al. The relationship between circulating endothelial microparticles and arterial stiffness and atherosclerosis in children with chronic kidney disease. Nephrol Dial Transplant. (2009) 24:2511-8. doi: 10.1093/ndt/gfp066

166. Yel S, Dursun I, Sahiner F, Baştug F, Tülpar S, Düşünsel R, et al. Increased circulating endothelial microparticles in children with FMF. Biomarkers (2018) 23:558-62.doi: 10.1080/1354750X.2018.1460764

167. Nieuwland R, Berckmans RJ, McGregor S, Böing AN, Romijn FP, Westendorp RG, et al. Cellular origin and procoagulant properties of microparticles in meningococcal sepsis. Blood (2000) 95:930-5.

168. Delabranche X, Boisramé-Helms J, Asfar P, Berger A, Mootien Y, Lavigne $\mathrm{T}$, et al. Microparticles are new biomarkers of septic shock-induced disseminated intravascular coagulopathy. Intensive Care Med. (2013) 39:1695-703. doi: 10.1007/s00134-013-2993-x

169. Matsumoto H, Yamakawa K, Ogura H, Koh T, Matsumoto N, Shimazu T. Enhanced expression of cell-specific surface antigens on endothelial microparticles in sepsis-induced disseminated intravascular coagulation. Shock (2015) 43:443-9.doi: 10.1097/SHK.0000000000000331

170. Mostefai HA, Meziani F, Mastronardi ML, Agouni A, Heymes C, Sargentini C, et al. Circulating microparticles from patients with septic shock exert protective role in vascular function. Am J Respir Crit Care Med. (2008) 178:1148-55. doi: $10.1164 / \mathrm{rccm} .200712-1835 \mathrm{OC}$

171. Soriano AO, Jy W, Chirinos JA, Valdivia MA, Velasquez HS, Jimenez $\mathrm{JJ}$, et al. Levels of endothelial and platelet microparticles and their interactions with leukocytes negatively correlate with organ dysfunction and predict mortality in severe sepsis. Crit Care Med. (2005) 33:2540-6. doi: 10.1097/01.CCM.0000186414.86162.03

172. da Silva EF, Fonseca FA, França CN, Ferreira PR, Izar MC, Salomão R, et al. Imbalance between endothelial progenitors cells and microparticles in HIVinfected patients naive for antiretroviral therapy. AIDS (2011) 25:1595-601. doi: 10.1097/QAD.0b013e32834980f4

173. Othman M, Labelle A, Mazzetti I, Elbatarny HS, Lillicrap D. Adenovirusinduced thrombocytopenia: the role of von Willebrand factor and Pselectin in mediating accelerated platelet clearance. Blood (2007) 109:2832-9. doi: 10.1182/blood-2006-06-032524

174. Bachelier K, Biehl S, Schwarz V, Kindermann I, Kandolf R, Sauter M, et al. Parvovirus B19-induced vascular damage in the heart is associated with elevated circulating endothelial microparticles. PLoS ONE (2017) 12:0176311. doi: 10.1371/journal.pone.0176311

175. Combes V, Taylor TE, Juhan-Vague I, Mège JL, Mwenechanya J, Tembo $\mathrm{M}$, et al. Circulating endothelial microparticles in malawian children with severe falciparum malaria complicated with coma. JAMA (2004) 291:2542-4. doi: 10.1001/jama.291.21.2542-b

176. Wassmer SC, Moxon CA, Taylor T, Grau GE, Molyneux ME, Craig AG. Vascular endothelial cells cultured from patients with cerebral or uncomplicated malaria exhibit differential reactivity to TNF. Cell Microbiol. (2011) 13:198-209. doi: 10.1111/j.1462-5822.2010.01528.x

177. Kay AB. Paul Ehrlich and the early history of granulocytes. Microbiol Spectr. (2016) 4. doi: 10.1128/microbiolspec.MCHD-0032-2016

178. Marelli-Berg FM, Jangani M. Metabolic regulation of leukocyte motility and migration. J Leukoc Biol. (2018) 104:285-93 doi: 10.1002/JLB.1MR1117-472R

179. Angelillo-Scherrer A. Leukocyte-derived microparticles in vascular homeostasis. Circ Res. (2012) 110:356-69. doi: 10.1161/CIRCRESAHA.110.233403

180. Mesri M, Altieri DC. Endothelial cell activation by leukocyte microparticles. J Immunol. (1998) 161:4382-7.

181. Mesri M, Altieri DC. Leukocyte microparticles stimulate endothelial cell cytokine release and tissue factor induction in a JNK1 signaling pathway. $J$ Biol Chem. (1999) 274:23111-8. doi: 10.1074/jbc.274.33.23111

182. Cerri C, Chimenti D, Conti I, Neri T, Paggiaro P, Celi A. Monocyte/macrophage-derived microparticles up-regulate inflammatory mediator synthesis by human airway epithelial cells. J Immunol. (2006) 177:1975-80. doi: 10.4049/jimmunol.177.3.1975

183. Neri T, Armani C, Pegoli A, Cordazzo C, Carmazzi Y, Brunelleschi S, et al. Role of NF-kappaB and PPAR-gamma in lung inflammation induced by monocyte-derived microparticles. Eur Respir J. (2011) 37:1494-502. doi: 10.1183/09031936.00023310

184. Eyre J, Burton JO, Saleem MA, Mathieson PW, Topham PS, Brunskill NJ. Monocyte- and endothelial-derived microparticles induce an inflammatory phenotype in human podocytes. Nephron Exp Nephrol. (2011) 119:58-66. doi: $10.1159 / 000329575$

185. Bardelli C, Amoruso A, Federici Canova D, Fresu L, Balbo P, Neri T, et al. Autocrine activation of human monocyte/macrophages by monocytederived microparticles and modulation by PPAR $\gamma$ ligands. $\mathrm{Br} J$ Pharmacol. (2012) 165:716-28. doi: 10.1111/j.1476-5381.2011.01593.x

186. Jüngel A, Distler O, Schulze-Horsel U, Huber LC, Ha HR, Simmen B, et al. Microparticles stimulate the synthesis of prostaglandin $\mathrm{E}(2)$ via induction of cyclooxygenase 2 and microsomal prostaglandin E synthase 1. Arthritis Rheum. (2007) 56:3564-74. doi: 10.1002/art.22980

187. Distler JH, Jüngel A, Huber LC, Seemayer CA, Reich CF $3^{\text {rd }}$, Gay RE, et al. The induction of matrix metalloproteinase and cytokine expression in synovial fibroblasts stimulated with immune cell microparticles. Proc Natl Acad Sci USA. (2005) 102:2892-7. doi: 10.1073/pnas.0409781102

188. Essayagh S, Xuereb JM, Terrisse AD, Tellier-Cirioni L, Pipy B, Sié P. Microparticles from apoptotic monocytes induce transient platelet recruitment and tissue factor expression by cultured human vascular endothelial cells via a redox-sensitive mechanism. Thromb Haemost. (2007) 98:831-7. doi: 10.1160/TH07-02-0082

189. Mastronardi ML, Mostefai HA, Soleti R, Agouni A, Martínez MC, Andriantsitohaina R. Microparticles from apoptotic monocytes enhance nitrosative stress in human endothelial cells. Fundam Clin Pharmaco. (2011) 25:653-60. doi: 10.1111/j.1472-8206.2010.00898.x

190. Forrester SJ, Kikuchi DS, Hernandes MS, Xu Q, Griendling KK. Reactive oxygen species in metabolic and inflammatory signaling. Circ Res. (2018) 122:877-902. doi: 10.1161/CIRCRESAHA.117.311401

191. Chiva-Blanch G, Bratseth V, Ritschel V, Andersen GØ, Halvorsen S, Eritsland J, et al. Monocyte-derived circulating microparticles (CD14+, $\mathrm{CD}_{14}{ }^{+} / \mathrm{CD}_{11 b^{+}}$and $\mathrm{CD} 14^{+} / \mathrm{CD}_{142}{ }^{+}$) are related to long-term prognosis for cardiovascular mortality in STEMI patients. Int J Cardiol. (2017) 227:876-81. doi: 10.1016/j.ijcard.2016.11.302

192. Ogata N, Nomura S, Shouzu A, Imaizumi M, Arichi M, Matsumura M. Elevation of monocyte-derived microparticles in patients with diabetic retinopathy. Diabetes Res Clin Pract. (2006) 73:241-8. doi: 10.1016/j.diabres.2006.01.014

193. Nomura S, Inami N, Shouzu A, Urase F, Maeda Y. Correlation and association between plasma platelet-, monocyte- and endothelial cell-derived microparticles in hypertensive patients with type 2 diabetes mellitus. Platelets (2009) 20:406-14. doi: 10.1080/09537100903114545

194. Pasquier J, Thomas B, Hoarau-Véchot J, Odeh T, Robay A, Chidiac O, et al. Circulating microparticles in acute diabetic Charcot foot exhibit a high content of inflammatory cytokines, and support monocyte-to-osteoclast cell induction. Sci Rep. (2017) 7:16450. doi: 10.1038/s41598-017-16365-7

195. Berckmans RJ, Nieuwland R, Tak PP, Böing AN, Romijn FP, Kraan MC, et al. Cell-derived microparticles in synovial fluid from inflamed arthritic joints support coagulation exclusively via a factor VII-dependent mechanism. Arthritis Rheum. (2002) 46:2857-66. doi: 10.1002/art.10587

196. Walsh KB, Campos B, Hart K, Thakar C, Adeoye O. M2 monocyte microparticles are increased in intracerebral hemorrhage. J Stroke Cerebrovasc Dis. (2017) 26:2369-75. doi: 10.1016/j.jstrokecerebrovasdis.2017.05.027

197. Kanazawa S, Nomura S, Kuwana M, Muramatsu M, Yamaguchi K, Fukuhara S. Monocyte-derived microparticles may be a sign of vascular complication in patients with lung cancer. Lung Cancer. (2003) 39:145-9. doi: 10.1016/S0169-5002(02)00441-5

198. Fujimi S, Ogura H, Tanaka H, Koh T, Hosotsubo H, Nakamori Y, et al. Activated polymorphonuclear leukocytes enhance production of leukocyte microparticles with increased adhesion molecules in patients with sepsis. J Trauma (2002) 52:443-8. doi: 10.1097/00005373-20020300000005

199. Wen B, Combes V, Bonhoure A, Weksler BB, Couraud PO, Grau GE. Endotoxin-induced monocytic microparticles have contrasting effects on endothelial inflammatory responses. PLoS ONE (2014) 9:91597. doi: 10.1371/journal.pone.0091597 
200. Dalli J, Montero-Melendez T, Norling LV, Yin X, Hinds C, Haskard $\mathrm{D}$, et al. Heterogeneity in neutrophil microparticles reveals distinct proteome and functional properties. Mol Cell Proteomics (2013) 12:2205-19. doi: 10.1074/mcp.M113.028589

201. Pluskota E, Woody NM, Szpak D, Ballantyne CM, Soloviev DA, Simon DI, et al. Expression, activation, and function of integrin alphaMbeta2 (Mac-1) on neutrophil-derived microparticles. Blood (2008) 112:2327-35. doi: 10.1182/blood-2007-12-127183

202. Butin-Israeli V, Houser MC, Feng M, Thorp EB, Nusrat A, Parkos CA, et al. Deposition of microparticles by neutrophils onto inflamed epithelium: a new mechanism to disrupt epithelial intercellular adhesions and promote transepithelial migration. FASEB J. (2016) 30:4007-20. doi: 10.1096/fj.201600734R

203. Slater TW, Finkielsztein A, Mascarenhas LA, Mehl LC, Butin-Israeli V, Sumagin R. Neutrophil microparticles deliver active myeloperoxidase to injured mucosa to inhibit epithelial wound healing. J Immunol. (2017) 198:2886-97. doi: 10.4049/jimmunol.1601810

204. Timár CI, Lorincz AM, Csépányi-Kömi R, Vályi-Nagy A, Nagy G, Buzás EI, et al. Antibacterial effect of microvesicles released from human neutrophilic granulocytes. Blood (2013) 121:510-8. doi: 10.1182/blood-2012-05-431114

205. Prakash PS, Caldwell CC, Lentsch AB, Pritts TA, Robinson BR. Human microparticles generated during sepsis in patients with critical illness are neutrophil-derived and modulate the immune response. J Trauma Acute Care Surg. (2012) 73:401-7.doi: 10.1097/TA.0b013e31825a776d

206. Johnson BL $3^{\text {rd }}$, Midura EF, Prakash PS, Rice TC, Kunz N, Kalies K, et al. Neutrophil derived microparticles increase mortality and the counterinflammatory response in a murine model of sepsis. Biochim Biophys Acta Mol Basis Dis. (2017)1863:2554-63.doi: 10.1016/j.bbadis.2017.01.012

207. Hyun YM, Sumagin R, Sarangi PP, Lomakina E, Overstreet MG, Baker $\mathrm{CM}$, et al. Uropod elongation is a common final step in leukocyte extravasation through inflamed vessels. J Exp Med. (2012) 209:1349-62. doi: $10.1084 /$ jem.20111426

208. Lim K, Sumagin R, Hyun YM. Extravasating neutrophil-derived microparticles preserve vascular barrier function in inflamed tissue. Immune Netw. (2013) 13:102-6. doi: 10.4110/in.2013.13.3.102

209. Gasser O, Schifferli JA. Activated polymorphonuclear neutrophils disseminate anti-inflammatory microparticles by ectocytosis. Blood (2004) 104:2543-8. doi: 10.1182/blood-2004-01-0361

210. Dalli J, Norling LV, Renshaw D, Cooper D, Leung KY, Perretti M. Annexin 1 mediates the rapid anti-inflammatory effects of neutrophil-derived microparticles. Blood (2008) 112:2512-9. doi: 10.1182/blood-2008-02-140533

211. Pliyev BK, Kalintseva MV, Abdulaeva SV, Yarygin KN, Savchenko VG. Neutrophil microparticles modulate cytokine production by natural killer cells. Cytokine (2014) 65:126-9. doi: 10.1016/j.cyto.2013.11.010

212. Scanu A, Molnarfi N, Brandt KJ, Gruaz L, Dayer JM, Burger D. Stimulated $\mathrm{T}$ cells generate microparticles, which mimic cellular contact activation of human monocytes: differential regulation of pro- and anti-inflammatory cytokine production by high-density lipoproteins. J Leukoc Biol. (2008) 83:921-7. doi: 10.1189/jlb.0807551

213. Carpintero R, Gruaz L, Brandt KJ, Scanu A, Faille D, Combes V, et al. HDL interfere with the binding of $\mathrm{T}$ cell microparticles to human monocytes to inhibit pro-inflammatory cytokine production. PLOS ONE (2010) 5:11869. doi: 10.1371/journal.pone.0011869

214. Shefler I, Salamon P, Reshef T, Mor A, Mekori YA. T cell-induced mast cell activation: a role for microparticles released from activated T cells. $J$ Immunol. (2010) 185:4206-12. doi: 10.4049/jimmunol.1000409

215. Shefler I, Pasmanik-Chor M, Kidron D, Mekori YA, Hershko AY. T cellderived microvesicles induce mast cell production of IL-24: relevance to inflammatory skin diseases. J Allergy Clin Immunol. (2014) 133:217-24. doi: 10.1016/j.jaci.2013.04.035

216. Shefler I, Salamon P, Levi-Schaffer F, Mor A, Hershko AY, Mekori YA. MicroRNA-4443 regulates mast cell activation by $\mathrm{T}$ cellderived microvesicles. J Allergy Clin Immunol. (2018) 141:2132-41. doi: 10.1016/j.jaci.2017.06.045

217. Martin S, Tesse A, Hugel B, Martínez MC, Morel O, Freyssinet JM, et al. Shed membrane particles from $\mathrm{T}$ lymphocytes impair endothelial function and regulate endothelial protein expression. Circulation (2004) 109:1653-9. doi: 10.1161/01.CIR.0000124065.31211.6E

218. Mostefai HA, Agouni A, Carusio N, Mastronardi ML, Heymes C, Henrion D, et al. Phosphatidylinositol 3-kinase and xanthine oxidase regulate nitric oxide and reactive oxygen species productions by apoptotic lymphocyte microparticles in endothelial cells. J Immunol. (2008) 180:502835. doi: 10.4049/jimmunol.180.7.5028

219. Qiu Q, Xiong W, Yang C, Gagnon C, Hardy P. Lymphocyte-derived microparticles induce bronchial epithelial cells' pro-inflammatory cytokine production and apoptosis. Mol Immunol. (2013) 55:220-30. doi: 10.1016/j.molimm.2013.01.017

220. Qiu Q, Xiong W, Yang C, Dai X, Dan X, Yang Z, et al. Lymphocytederived microparticles induce apoptosis of airway epithelial cells through activation of p38 MAPK and production of arachidonic acid. Apoptosis (2014) 19:1113-27. doi: 10.1007/s10495-014-0993-0

221. Qiu Q, Yang C, Xiong W, Tahiri H, Payeur M, Superstein R, et al SYK is a target of lymphocyte-derived microparticles in the induction of apoptosis of human retinoblastoma cells. Apoptosis (2015) 20:1613-22. doi: 10.1007/s10495-015-1177-2

222. Kornek M, Popov Y, Libermann TA, Afdhal NH, Schuppan D. Human $\mathrm{T}$ cell microparticles circulate in blood of hepatitis patients and induce fibrolytic activation of hepatic stellate cells. Hepatology (2011) 53:230-42. doi: 10.1002/hep.23999

223. Kornek M, Lynch M, Mehta SH, Lai M, Exley M, Afdhal NH, et al. Circulating microparticles as disease-specific biomarkers of severity of inflammation in patients with hepatitis $\mathrm{C}$ or nonalcoholic steatohepatitis. Gastroenterology (2012) 143:448-58. doi: 10.1053/j.gastro.2012.04.031

224. López P, Rodríguez-Carrio J, Martínez-Zapico A, Caminal-Montero L, Suárez A. Circulating microparticle subpopulations in systemic lupus erythematosus are affected by disease activity. Int J Cardiol. (2017) 236:13844. doi: 10.1016/j.ijcard.2017.02.107

225. Fan W, Wang W, Wu J, Ma L, Guo J. Identification of $\mathrm{CD}^{+}{ }^{+} \mathrm{T}$ cell-derived $\mathrm{CD}_{161}{ }^{+} \mathrm{CD} 39^{+}$and $\mathrm{CD} 39^{+} \mathrm{CD}^{+} 3^{+}$microparticles as new biomarkers for rheumatoid arthritis. Biomark Med. (2017) 11:107-16. doi: 10.2217/bmm-2016-0261

226. Zinger A, Latham SL, Combes V, Byrne S, Barnett MH, Hawke S, et al. Plasma levels of endothelial and B-cell-derived microparticles are restored by fingolimod treatment in multiple sclerosis patients. Mult Scler. (2016) 22:1883-7. doi: 10.1177/1352458516636959

227. Li JJ, Wang B, Kodali MC, Chen C, Kim E, Patters BJ, et al. In vivo evidence for the contribution of peripheral circulating inflammatory exosomes to neuroinflammation. J Neuroinflammation (2018) 15:8. doi: 10.1186/s12974-017-1038-8

228. Ye W, Tang X, Yang Z, Liu C, Zhang X, Jin J, et al. Plasma-derived exosomes contribute to inflammation via the TLR9-NF- $\mathrm{B}$ pathway in chronic heart failure patients. Mol Immunol. (2017) 87:114-21. doi: 10.1016/j.molimm.2017.03.011

229. Kojima M, Gimenes-Junior JA, Chan TW, Eliceiri BP, Baird A, Costantini TW, et al. Exosomes in postshock mesenteric lymph are key mediators of acute lung injury triggering the macrophage activation via Toll-like receptor 4. FASEB J. (2018) 32:97-110. doi: 10.1096/fj.201700488R

230. Feng Y, Lv LL, Wu WJ, Li ZL, Chen J, Ni HF, et al. Urinary exosomes and exosomal CCL2 mRNA as biomarkers of active histological injury in immunoglobulin a nephropathy. Am J Pathol. (2018) 188:2542-52. doi: 10.1016/j.ajpath.2018.07.017

231. Hadley EE, Sheller-Miller S, Saade G, Salomon C, Mesiano S, Taylor RN, et al. Amnion epithelial cell derived exosomes induce inflammatory changes in uterine cells. Am J Obstet Gynecol. (2018) 219:478. doi: 10.1016/j.ajog.2018.08.021

232. Esser J, Gehrmann U, D’Alexandri FL, Hidalgo-Estévez AM, Wheelock $\mathrm{CE}$, Scheynius A, et al. Exosomes from human macrophages and dendritic cells contain enzymes for leukotriene biosynthesis and promote granulocyte migration. J Allergy Clin Immunol. (2010) 126:1032-40. doi: 10.1016/j.jaci.2010.06.039

233. Singhto N, Thongboonkerd V. Exosomes derived from calcium oxalate-exposed macrophages enhance IL-8 production from renal cells, neutrophil migration and crystal invasion through extracellular 
matrix. J Proteomics (2018) 185:64-76. doi: 10.1016/j.jprot.2018. 06.015

234. Bhatnagar S, Schorey JS. Exosomes released from infected macrophages contain Mycobacterium avium glycopeptidolipids and are proinflammatory. J Biol Chem. (2007) 282:25779-89. doi: 10.1074/jbc.M702277200

235. Zitvogel L, Regnault A, Lozier A, Wolfers J, Flament C, Tenza D, et al. Eradication of established murine tumors using a novel cell-free vaccine: dendritic cell-derived exosomes. Nat Med. (1998) 4:594-600. doi: 10.1038/nm0598-594

236. Skokos D, Le Panse S, Villa I, Rousselle JC, Peronet R, David B, et al. Mast cell-dependent $\mathrm{B}$ and $\mathrm{T}$ lymphocyte activation is mediated by the secretion of immunologically active exosomes. J Immunol. (2001) 166:86876. doi: 10.4049/jimmunol.166.2.868

237. Liu H, Gao W, Yuan J, Wu C, Yao K, Zhang L, et al. Exosomes derived from dendritic cells improve cardiac function via activation of CD4(+) T lymphocytes after myocardial infarction. J Mol Cell Cardiol. (2016) 91:12333. doi: $10.1016 /$ j.yjmcc.2015.12.028

238. Hong X, Schouest B, Xu H. Effects of exosome on the activation of CD4+ T cells in rhesus macaques: a potential application for HIV latency reactivation. Sci Rep. (2017) 7:15611. doi: 10.1038/s41598-017-15961-x

239. Alexander M, Hu R, Runtsch MC, Kagele DA, Mosbruger TL, Tolmachova $\mathrm{T}$, et al. Exosome-delivered microRNAs modulate the inflammatory response to endotoxin. Nat Commun. (2015) 6:7321. doi: 10.1038/ncomms8321

240. Bala S, Petrasek J, Mundkur S, Catalano D, Levin I, Ward J, et al. Circulating microRNAs in exosomes indicate hepatocyte injury and inflammation in alcoholic, drug-induced, and inflammatory liver diseases. Hepatology (2012) 56:1946-57. doi: 10.1002/hep.25873

241. Wang C, Zhang C, Liu L, A X, Chen B, Li Y, et al. Macrophage-derived mir-155-containing exosomes suppress fibroblast proliferation and promote fibroblast inflammation during cardiac injury. Mol Ther. (2017) 25:192-204. doi: 10.1016/j.ymthe.2016.09.001

242. Huang S, Ge X, Yu J, Han Z, Yin Z, Li Y, et al. Increased miR-124-3p in microglial exosomes following traumatic brain injury inhibits neuronal inflammation and contributes to neurite outgrowth via their transfer into neurons. FASEB J. (2018) 32:512-28. doi: 10.1096/fj.201700673R

243. Chen L, Lu FB, Chen DZ, Wu JL, Hu ED, Xu LM, et al. BMSCsderived miR-223-containing exosomes contribute to liver protection in experimental autoimmune hepatitis. Mol Immunol. (2018) 93:38-46. doi: 10.1016/j.molimm.2017

244. Liu J, Jiang M, Deng S, Lu J, Huang H, Zhang Y, et al. miR-93-5pcontaining exosomes treatment attenuates acute myocardial infarctioninduced myocardial damage. Mol Ther Nucleic Acids (2018) 11:103-15. doi: 10.1016/j.omtn.2018.01.010

245. Barros FM, Carneiro F, Machado J, Melo SA. Exosomes and immune response in cancer: friends or foes? Front Immunol. (2018) 9:730. doi: $10.3389 /$ fimmu.2018.00730

246. Kim SH, Lechman ER, Bianco N, Menon R, Keravala A, Nash J, et al. Exosomes derived from IL-10-treated dendritic cells can suppress inflammation and collagen-induced arthritis. J Immunol. (2005) 174:6440-8. doi: 10.4049/jimmunol.174.10.6440

247. Kim SH, Bianco NR, Shufesky WJ, Morelli AE, Robbins PD. MHC class II + exosomes in plasma suppress inflammation in an antigen-specific and Fas ligand/Fas-dependent manner. J Immunol. (2007) 179:2235-41. doi: 10.4049/jimmunol.179.4.2235

248. Huang JH, Yin XM, Xu Y, Xu CC, Lin X, Ye FB, et al. Systemic administration of exosomes released from mesenchymal stromal cells attenuates apoptosis, inflammation, and promotes angiogenesis after spinal cord injury in rats. $J$ Neurotrauma (2017) 34:3388-96. doi: 10.1089/neu.2017.5063

249. Cosenza S, Toupet K, Maumus M, Luz-Crawford P, Blanc-Brude O, Jorgensen C, et al. Mesenchymal stem cells-derived exosomes are more immunosuppressive than microparticles in inflammatory arthritis. Theranostics (2018) 8:1399-410. doi: 10.7150/thno.21072

250. Torreggiani E, Perut F, Roncuzzi L, Zini N, Baglio SR, Baldini N. Exosomes: novel effectors of human platelet lysate activity. Eur Cell Mater. (2014) 28:137-51. doi: 10.22203/eCM.v028a11

251. Cabral J, Ryan AE, Griffin MD, Ritter T. Extracellular vesicles as modulators of wound healing. Adv Drug Deliv Rev. (2018) 129:394-406. doi: 10.1016/j.addr.2018.01.018
252. Yuana Y, Sturk A, Nieuwland R. Extracellular vesicles in physiological and pathological conditions. Blood Rev. (2013) 27:31-9. doi: $10.1016 /$ j.blre.2012.12.002

253. Iida K, Whitlow MB, Nussenzweig V. Membrane vesiculation protects erythrocytes from destruction by complement. J Immunol. (1991) 147:263842.

254. Abid Hussein MN, Böing AN, Sturk A, Hau CM, Nieuwland R. Inhibition of microparticle release triggers endothelial cell apoptosis and detachment. Thromb Haemost. (2007) 98:1096-107.

255. Deppermann C, Kubes P. Start a fire, kill the bug: the role of platelets in inflammation and infection. Innate Immun. (2018) 24:335-48. doi: $10.1177 / 1753425918789255$

256. Nomura S. Extracellular vesicles and blood diseases. Int J Hematol. (2017) 105:392-405. doi: 10.1007/s12185-017-2180-x

257. Castaman G, Yu-Feng L, Rodeghiero F. A bleeding disorder characterised by isolated deficiency of platelet microvesicle generation. Lancet (1996) 347:700-1.doi: 10.1016/S0140-6736(96)91259-3

258. Castaman G, Yu-Feng L, Battistin E, Rodeghiero F. Characterization of a novel bleeding disorder with isolated prolonged bleeding time and deficiency of platelet microvesicle generation. Br J Haematol. (1997) 96:45863. doi: 10.1046/j.1365-2141.1997.d01-2072.x

259. Westerman M, Porter JB. Red blood cell-derived microparticles: an overview. Blood Cells Mol Dis. (2016) 59:134-9. doi: 10.1016/j.bcmd.2016.04.003

260. Auer J. The structure and function of filaments produced by living red corpuscles. Am J Med Sci. (1933) 186:776-94.

261. Awojoodu AO, Keegan PM, Lane AR, Zhang Y, Lynch KR, Platt MO, et al. Acid sphingomyelinase is activated in sickle cell erythrocytes and contributes to inflammatory microparticle generation in SCD. Blood (2014) 124:1941-50. doi: 10.1182/blood-2014-01-543652

262. Xie R, Yang Y, Zhu Y, Gao L, Jiang X, Sun J, et al. Microparticles in red cell concentrates prime polymorphonuclear neutrophils and cause acute lung injury in a two-event mouse model. Int Immunopharmacol. (2018) 55:98-104. doi: 10.1016/j.intimp.2017.11.029

263. Sadallah S, Eken C, Schifferli JA. Erythrocyte-derived ectosomes have immunosuppressive properties. J Leukoc Biol. (2008) 84:1316-25. doi: $10.1189 /$ jlb.0108013

264. Mehrfeld C, Zenner S, Kornek M, Lukacs-Kornek V. The contribution of non-professional antigen-presenting cells to immunity and tolerance in the liver. Front Immunol. (2018) 9:635. doi: 10.3389/fimmu.2018.00635

265. Witek RP, Yang L, Liu R, Jung Y, Omenetti A, Syn WK, et al. Liver cell-derived microparticles activate hedgehog signaling and alter gene expression in hepatic endothelial cells. Gastroenterology (2009) 136:320-30. doi: 10.1053 /j.gastro.2008.09.066.

266. Herrera MB, Fonsato V, Gatti S, Deregibus MC, Sordi A, Cantarella $D$, et al. Human liver stem cell-derived microvesicles accelerate hepatic regeneration in hepatectomized rats. J Cell Mol Med. (2010) 14:1605-18. doi: $10.1111 / j .1582-4934.2009 .00860 . x$

267. Julich-Haertel H, Urban SK, Krawczyk M, Willms A, Jankowski K, Patkowski W, et al. Cancer-associated circulating large extracellular vesicles in cholangiocarcinoma and hepatocellular carcinoma. J Hepatol. (2017) 67:282-92. doi: 10.1016/j.jhep.2017.02.024

268. Hirsova P, Ibrahim SH, Krishnan A, Verma VK, Bronk SF, Werneburg NW, et al. Lipid-induced signaling causes release of inflammatory extracellular vesicles from hepatocytes. Gastroenterology (2016) 150:956-67. doi: 10.1053 /j.gastro.2015.12.037

269. Ibrahim SH, Hirsova P, Tomita K, Bronk SF, Werneburg NW, Harrison $\mathrm{SA}$, et al. Mixed lineage kinase 3 mediates release of C-X-C motif ligand 10-bearing chemotactic extracellular vesicles from lipotoxic hepatocytes. Hepatology (2016) 63:731-44. doi: 10.1002/hep.28252

270. Kakazu E, Mauer AS, Yin M, Malhi H. Hepatocytes release ceramideenriched pro-inflammatory extracellular vesicles in an IRE1 $\alpha$ dependent manner. J Lipid Res. (2016) 57:233-45. doi: 10.1194/jlr.M0 63412

271. Garcia-Martinez I, Santoro N, Chen Y, Hoque R, Ouyang X, Caprio S, et al. Hepatocyte mitochondrial DNA drives nonalcoholic steatohepatitis by activation of TLR9. J Clin Invest. (2016) 126:859-64. doi: 10.1172/JCI83885

272. Huang R, Pan Q, Ma X, Wang Y, Liang Y, Dai B, et al. Hepatic stellate cell-derived microvesicles prevent hepatocytes from injury 
induced by APAP/H2O2. Stem Cells Int. (2016) 2016:8357567. doi: $10.1155 / 2016 / 8357567$

273. Bianco F, Pravettoni E, Colombo A, Schenk U, Möller T, Matteoli $\mathrm{M}$, et al. Astrocyte-derived ATP induces vesicle shedding and IL1 beta release from microglia. J Immunol. (2005) 174:7268-77. doi: $10.4049 /$ jimmunol.174.11.7268

274. Bianco F, Perrotta C, Novellino L, Francolini M, Riganti L, Menna E, et al. Acid sphingomyelinase activity triggers microparticle release from glial cells. EMBO J. (2009) 28:1043-54. doi: 10.1038/emboj.2009.45

275. Scolding NJ, Morgan BP, Houston WA, Linington C, Campbell AK, Compston DA. Vesicular removal by oligodendrocytes of membrane attack complexes formed by activated complement. Nature (1989) 339:620-2. doi: $10.1038 / 339620 \mathrm{a} 0$

276. Hayakawa K, Esposito E, Wang X, Terasaki Y, Liu Y, Xing C, et al. Transfer of mitochondria from astrocytes to neurons after stroke. Nature (2016) 535:551-5. doi: 10.1038/nature18928

277. Ridger VC, Boulanger CM, Angelillo-Scherrer A, Badimon L, Blanc-Brude $\mathrm{O}$, Bochaton-Piallat ML, et al. Microvesicles in vascular homeostasis and diseases. Position paper of the European Society of Cardiology (ESC) working group on atherosclerosis and vascular biology. Thromb Haemost. (2017) 117:1296-316. doi: 10.1160/TH16-12-0943

278. Garcia-Romero N, Esteban-Rubio S, Rackov G, Carrión-Navarro J, Belda-Iniesta C, Ayuso-Sacido A. Extracellular vesicles compartment in liquid biopsies: clinical application. Mol Aspects Med. (2018) 60:27-37. doi: 10.1016/j.mam.2017.11.009

279. Chiriacò MS, Bianco M, Nigro A, Primiceri E, Ferrara F, Romano A, et al. Lab-on-chip for exosomes and microvesicles detection and characterization. Sensors (Basel) (2018) 18:E3175 .doi: 10.3390/s18103175

280. Tucher C, Bode K, Schiller P, Claßen L, Birr C, Souto-Carneiro MM, et al. Extracellular vesicle subtypes released from activated or apoptotic Tlymphocytes carry a specific and stimulus-dependent protein cargo. Front Immunol. (2018) 9:534. doi: 10.3389/fimmu.2018.00534

281. Kishore A, Navratilova Z, Kolek V, Novosadova E, Čépe K, du Bois RM, et al. Expression analysis of extracellular microRNA in bronchoalveolar lavage fluid from patients with pulmonary sarcoidosis. Respirology. (2018) 23:1166-1172. doi: 10.1111/resp.13364

282. Słomka A, Piekuś A, Kowalewski M, Pawliszak W, Anisimowicz L, Zekanowska E. Assessment of the procoagulant activity of microparticles and the protein $\mathrm{Z}$ system in patients undergoing off-pump coronary artery bypass surgery. Angiology (2018) 69:347-57. doi: 10.1177/0003319717706616

283. Ramirez MI, Amorim MG, Gadelha C, Milic I, Welsh JA, Freitas VM, et al. Technical challenges of working with extracellular vesicles. Nanoscale (2018) 10:881-906. doi: 10.1039/c7nr08360b

284. Shao H, Im H, Castro CM, Breakefield X, Weissleder R, Lee H. New technologies for analysis of extracellular vesicles. Chem Rev. (2018) 118:1917-50. doi: 10.1021/acs.chemrev.7b00534

285. Sun D, Zhuang X, Xiang X, Liu Y, Zhang S, Liu C, et al. A novel nanoparticle drug delivery system: the anti-inflammatory activity of curcumin is enhanced when encapsulated in exosomes. Mol Ther. (2010) 18:1606-14. doi: $10.1038 / \mathrm{mt} .2010 .105$
286. Zhuang X, Xiang X, Grizzle W, Sun D, Zhang S, Axtell RC, et al. Treatment of brain inflammatory diseases by delivering exosome encapsulated antiinflammatory drugs from the nasal region to the brain. Mol Ther. (2011) 19:1769-79. doi: 10.1038/mt.2011.164

287. Ohno S, Takanashi M, Sudo K, Ueda S, Ishikawa A, Matsuyama $\mathrm{N}$, et al. Systemically injected exosomes targeted to EGFR deliver antitumor microRNA to breast cancer cells. Mol Ther .(2013) 21:185-91. doi: 10.1038/mt.2012.180

288. Kamerkar S, LeBleu VS, Sugimoto H, Yang S, Ruivo CF, Melo SA, et al Exosomes facilitate therapeutic targeting of oncogenic KRAS in pancreatic cancer. Nature (2017) 546:498-503. doi: 10.1038/nature22341

289. Cooper JM, Wiklander PB, Nordin JZ, Al-Shawi R, Wood MJ, Vithlani $\mathrm{M}$, et al. Systemic exosomal siRNA delivery reduced alpha-synuclein aggregates in brains of transgenic mice. Mov Disord. (2014) 29:1476-85. doi: $10.1002 / \mathrm{mds} .25978$

290. Haney MJ, Klyachko NL, Zhao Y, Gupta R, Plotnikova EG, He $Z$, et al. Exosomes as drug delivery vehicles for Parkinson's disease therapy. J Control Release (2015) 207:18-30. doi: 10.1016/j.jconrel.2015. 03.033

291. Escudier B, Dorval T, Chaput N, André F, Caby MP, Novault S, et al. Vaccination of metastatic melanoma patients with autologous dendritic cell (DC) derived-exosomes: results of the first phase I clinical trial. J Transl Med. (2005) 3:10. doi: 10.1186/1479-5876-3-10

292. Morse MA, Garst J, Osada T, Khan S, Hobeika A, Clay TM, et al. A phase I study of dexosome immunotherapy in patients with advanced nonsmall cell lung cancer. J Transl Med. (2005) 3:9. doi: 10.1186/1479-587 6-3-9

293. Besse B, Charrier M, Lapierre V, Dansin E, Lantz O, Planchard D, et al. Dendritic cell-derived exosomes as maintenance immunotherapy after first line chemotherapy in NSCLC. Oncoimmunology (2015) 5:1071008. doi: 10.1080/2162402X.2015.1071008

294. Tang K, Zhang Y, Zhang H, Xu P, Liu J, Ma J, et al. Delivery of chemotherapeutic drugs in tumour cell-derived microparticles. Nat Commun. (2012) 3:1282. doi: 10.1038/ncomms2282

295. Mizrak A, Bolukbasi MF, Ozdener GB, Brenner GJ, Madlener S, Erkan EP, et al. Genetically engineered microvesicles carrying suicide mRNA/protein inhibit schwannoma tumor growth. Mol Ther. (2013) 21:101-8. doi: 10.1038/mt.2012.161

Conflict of Interest Statement: The authors declare that the research was conducted in the absence of any commercial or financial relationships that could be construed as a potential conflict of interest.

Copyright $\odot 2018$ Stomka, Urban, Lukacs-Kornek, Żekanowska and Kornek. This is an open-access article distributed under the terms of the Creative Commons Attribution License (CC BY). The use, distribution or reproduction in other forums is permitted, provided the original author(s) and the copyright owner(s) are credited and that the original publication in this journal is cited, in accordance with accepted academic practice. No use, distribution or reproduction is permitted which does not comply with these terms. 